\title{
Towards the Evaluation of the Ecological Effectiveness of the Principles, Criteria and Indicators (PCI) of the Forest Stewardship Council (FSC): Case study in the Arkhangelsk Region in the Russian Federation
}

Jeanette S Blumroeder ${ }^{1, *}$, Peter R Hobson ${ }^{2}$, Uli F Graebener ${ }^{3}$, Jörg-Andreas Krüger ${ }^{3}$, Denis Dobrynin ${ }^{4}$, Natalya Burova $^{5}$, Irina Amosa ${ }^{5}$, Susanne Winter ${ }^{3}$ and Pierre L Ibisch ${ }^{1}$

${ }^{1}$ Centre for Econics and Ecosystem Management, Eberswalde University for Sustainable Development, Eberswalde, Germany

${ }^{2}$ Centre for Econics and Ecosystem Management, Writtle University College, Writtle Chelmsford Essex, United Kingdom

3 WWF Germany, Berlin, Germany

${ }^{4}$ WWF Russia, Arkhangelsk, Russia

${ }^{5}$ Northern (Arctic) Federal University, Arkhangelsk, Russia

* Corresponding author: E-Mail: j.blumroeder@hnee.de; Tel.: +49 3334657229; Fax: +49 3334657162

Submitted: 24 July 2017 | In revised form: 7 March 2018 | Accepted: 26 April 2018 |

Published: 14 June 2018

\begin{abstract}
The Forest Stewardship Council (FSC) is a voluntary sustainability standard with global reach that has been developed to encourage responsible and sustainable forest management. Despite its broad appeal, there is little scientific assessment to substantiate the effectiveness of FSC in the boreal zone. In this study, an ecosystem-based and participatory approach was applied to a case study in the Arkhangelsk Region of the Russia Federation to assess the potential influence of the principles, criteria and indicators of the Russian FSC standard. An ECOSEFFECT theoretical plausibility analysis was conducted to evaluate the potential effectiveness of FSC in safeguarding the ecological integrity of the ecosystem. Besides spatial analysis and a field visitation, core elements of the methodological procedure were workshops with experts and stakeholders who directly contributed to knowledge mapping and analysis. The results of the study suggest FSC can potentially influence and improve forest management including monitoring and evaluation, foster the institutional capacity, and enhance knowledge on the impacts of forest management. Theoretically, FSC has a certain potential to reduce a range of anthropogenic threats to the ecosystem, such as large-scale deforestation and forest degradation, logging of High Conservation Value Forests, large size of clear-cuts, excessive annual allowable cuts, damage to trees during forest operations, and hydrological changes. However, human-induced fire is the only ecological stress that was assumed to be effectively tackled through a strong and positive influence of FSC. The results of the theoretical analysis with a semi-quantitative evaluation revealed the potential for FSC to generate much more effective outcomes for biodiversity by prudently targeting key ecological problems. The biggest problem is the large-scale clear-cutting practice, especially within IFL. These devastating practices are not promoted by, but are compliant with the current Russian FSC standard. This feeds doubts about the consistency of FSC practice and its credibility.
\end{abstract}

Keywords: Arkhangelsk; boreal forest; ecological effectiveness; FSC-certification; sustainability 


\section{Introduction}

The Forest Stewardship Council (FSC) is a voluntary sustainability standard developed to promote responsible management of the world's forests that is environmentally appropriate, socially beneficial, and economically viable [1]. Based on a generic certification system with a given set of general principles and criteria, 46 national standards for 38 different countries have been formulated and approved, each with their own specific indicators, verifiers, norms, and guidance [2]. FSC is a market-based tool that has been prepared by a multi-stakeholder group and is the most widely adopted forest standard, already covering 196 million hectares of the forest across 83 different countries worldwide [3]. Motivated by ethical concerns for the environment and underpinned by the Sustainable Development Goals as well as international directives to safeguard biodiversity, FSC is regarded as a powerful instrument to achieve Sustainable Forest Management (SFM) [4]. SFM aims to commercially use forests without compromising biodiversity, biomass productivity, the capacity for natural regeneration, vitality, and the functionality to provide ecosystem services in the long-term and without threatening other ecological systems [5].

The concept of SFM seems to be in accordance with the requirements of the ecosystem approach [6]; at least both pursue the same ultimate goals [7]. The ecosystem approach promotes the conservation of biodiversity and sustainable use of natural resources taking into account the inherent dynamics and complexity of ecological systems [8]. It acknowledges the close interrelation and interdependency of ecological and anthropogenic systems as well as the need for protecting biodiversity when utilizing natural resources [9]. The reduction of present and future anthropogenic threats to biodiversity fosters ecosystem resilience by supporting ecosystem functionality in the long-term, and in doing so, increasing the ability of ecosystems to cope with perturbations and environmental changes [10,11].

Growing scientific evidence indicates that forest certification probably decreases social and environmental shortcomings [12]. FSC members are convinced that FSC certification generates social benefits such as improved communication processes and the resolution of conflicts [13]. For instance, FSC certification induced beneficial social outcomes in terms of living conditions of forest workers and benefit-sharing in the Congo basin [14]. In Tanzania, FSC-certified community forests showed improved forest structure and forest regeneration as well as a less fire incidents [15]. Nevertheless, the effects of FSC certification on the management of community forests are often limited and do not necessarily refer to certification itself, but to the emphasis of public policy and positive institutional influence [16]. Regarding short-term environmental impacts, FSC certification led to a slight reduction in logging damage, impacts from skidding trails and roads, and loss of above-ground biomass in Gabon [17]. In Indonesia, FSC certification decreased deforestation and air pollution and was associated with benefits to local communities including health issues, but still, forest management for timber harvesting causes ecosystem disturbance [18]. Amongst three different commercial forest reserves in Malaysia, mammal species richness including threatened species and aboveground biomass were highest in a FSC-certified area [19]. In Mediterranean oak woodlands, FSC had a positive effect on stream quality after five years by enhancing riparian vegetation [20]. In a global panel analysis it was concluded that forest certification can reduce deforestation directly and indirectly [21]. However, logging activities under FSC cannot always be associated with lower carbon emissions [22].

More than one fifth of the world's FSC-certified area is located within the Russian Federation [3]. The increasing demand for certified timber together with an active promotion from international organisations, especially from environmental NGOs, has been the main driving force behind FSC certification in the Russian Federation [23]. However, evidence for the environmental benefits of FSC is to be found mainly in the tropical and subtropical biomes. In contrast, there have been very few studies published on FSC practices in boreal forests, and those that have are restricted to EU-countries such as Sweden or Finland, and to North America. A study conducted in 12 stands in the USA concluded that FSC-certified harvesting showed no significant differences at stand level in comparison to noncertified forestry, except for an increase in woody residues [24]. In the boreal forests of the Russian Federation less evidence about the impacts of FSC certification was produced. Maintaining the functionality of the Russian forests is highly relevant, as forest cover in the Russian Federation is the most extensive of all the larger countries [25]. In 2010, forest was estimated to cover almost 800 million hectares of the Russian territory [26].

The taiga represents a boreal forest ecosystem encompassing the largest terrestrial biome on the globe, but much of the natural structures and dynamics have been heavily impacted by anthropogenic exploitation [27]. In the production forests of the Russian Federation clear-cuts of up to 50 ha are allowed in accordance with the forest code [28]. In more recent times, the predominantly high intensity timber logging, clear-cuttings, and human-induced fires have caused substantial tree cover losses and ecosystem degradation [29]. The transformation from intact forest landscapes (IFL) to forests that are deeply fragmented, especially in European Russia, changed the ecology of the region and threatens to reduce ecosystem functionality in the long-term [30]. At present, within the Arkhangelsk Region and the Komi Republic, large tracts of IFL remain [31], but at the same time these areas continue to suffer from substantive tree cover loss [29,32]. The FSC promotes the preservation of IFL as part of high conservation value forests (HCVF) [33]. The reduction of logging in primary forests and the identification of HCVF were encountered as positive environmental impacts of FSC that contribute to biodiversity conservation in the Russian Federation [23]. Specifically, in tracts of forest managed as clear-cut, those areas spared from felling are 
important landscape elements for biodiversity and are promoted by FSC certification [34]. Nevertheless, most studies about the impacts of FSC in the Russian Federation focus on issues relating to governance and society [35-38], and much less on ecological effects.

In this study, an ecosystem-based and participatory methodology, named ECOSEFFECT, is applied to systemically assess and evaluate the principles, criteria and indicators (PCI) of FSC and their potential for reducing recognized environmental threats to biodiversity that result from conventional forest management practices. ECOSEFFECT has been developed specifically to assess the performance of certification systems for the sustainable management of natural resources with a focus on maintaining ecosystem functionality. The Arkhangelsk Region was the chosen study site because of its relevance for timber supply in Europe and Russia, and also because it supports large tracts of intact forest, but most crucial is the recent expansion of FSC across the forest leaseholders. The main aim of the study was to estimate the potential benefits derived from implementing the $\mathrm{PCl}$ of $\mathrm{FSC}$ in the Arkhangelsk Region, and to identify eventual challenges and shortcomings of the standard.

\section{Method}

\subsection{Geographical Scope}

The Arkhangelsk Region is located in the north-west of the Russian Federation, bordered to the north by the White Sea and Nenetskiy, to the east by the Komi Republic, the Karelia Republic to the west, and the Vologda Region and Kirov Region to the south. The subarctic climate of the boreal moist forest biome is characterised by cold and long winters, and short summers, which sets limits on the growing season for plants. The mean annual temperature is $1.5^{\circ} \mathrm{C}$ and annual precipitation around $670 \mathrm{~mm}$ [39]. Forest covers the largest part of the land surface with a share of about $39 \%$, of which approximately one third is classified as IFL [40]. The coniferous spruce forests are adapted to the harsh growing conditions. With about two persons per square kilometre on average, the Arkhangelsk Region is quite sparsely populated [41]. The economy is based predominantly on timber extraction and processing, and by the beginning of the 20th century, Archangelsk was already one of the largest sawmilling regions in the world [42]. After a dip in productivity after the collapse of the Soviet Union [43], the region again has become a centre of Russian forestry [44].

\subsection{Conceptual Scope and General Methodological Approach}

The methodological framework ECOSEFFECT (ECOsystem-based assessment of Sustainability stan- dards and their EFFECTiveness), used in this study is based on MARISCO, an adaptive and proactive conservation management tool $[45,46]$. The applied method is grounded in an ecosystem approach which includes the principle that humans and their economic activities are an integral part of the global ecosystem and depend on the full functioning of ecosystems. In the case of forests and their management it becomes especially apparent that both economic and social sustainability entirely depend on the functioning of the ecosystem. For this reason we postulate a clear 'hierarchy of sustainabilities' reflecting that the sustainable existence and functioning of the ecosystem is a conditio sine qua non for any dependent subsystem. To justify the development and use of a sustainability standard for ecosystem management such as FSC requires proof of its effectiveness in safeguarding the ecology and the integrity of the service-provisioning system. Beneficial influences of FSC on the social and economic sphere can be important achievements, which are very much appreciated, but if short-term benefits for human well-being do not translate into potential ecological outcomes then they are irrelevant to our study (e.g., safety requirements that lead to reduced injuries of forest workers does not induce any positive impacts in the forest ecosystem [47]). Nevertheless, we fully recognize the complexity inherent in nature and its relationship with society. The evaluation of the benefits and gains made by applying certification cannot focus solely on changes in forests and forest management operations, but also requires an analytical framework that carefully considers the causal origin of outcomes [48]. ECOSEFFECT scrutinizes the human-induced threats to ecosystems and the ability of sustainability standards to reduce the resulting ecological stresses by abating the underlying drivers of negative environmental change. The human dimension, including social and economic aspects, appears in the analysis as the drivers of environmental change on the one hand and on the other hand human well-being is directly affected by the consequences of deteriorated ecosystems. The approach taken deliberately applies a systemic framework with as much of the complex situation and prevailing conditions represented as possible. It pools information from experts and stakeholders, and is an open-source, transparent knowledge sharing platform with the purpose of understanding different view-points and angles of interpretation.

\subsection{Theoretical Plausibility Analysis}

A theoretical plausibility analysis was conducted according to a series of procedural steps making up the ECOSEFFECT method (Table 1) [49]. 
Table 1. Methodological steps of the ECOSEFFECT method that were conducted in this study.

\begin{tabular}{|c|c|c|}
\hline & $\begin{array}{c}\text { Details and content of the ECOSEFFECT } \\
\text { methodological steps }\end{array}$ & Output \\
\hline $\begin{array}{l}\text { 1. Ecosystem } \\
\text { Diagnostics } \\
\text { Analysis (EDA) }\end{array}$ & $\begin{array}{l}\text { - Examination of available spatial data } \\
\text { on land cover and land-use change } \\
\text { - Meetings with forest managers and } \\
\text { visitation of forest sites that have been logged } \\
\text { recently and a longer time ago, with and } \\
\text { without FSC-certification } \\
\text { - Obtaining further information from } \\
\text { local experts and stakeholders } \\
\text { - Verification of spatial data }\end{array}$ & $\begin{array}{l}\text { Maps and impression about the } \\
\text { landscape, the distribution of } \\
\text { forests, natural and } \\
\text { anthropogenic land-use change } \\
\text { in the Arkhangelsk Region and } \\
\text { tree cover loss in particular }\end{array}$ \\
\hline $\begin{array}{l}\text { 2.Situation } \\
\text { Analysis }\end{array}$ & $\begin{array}{l}\text { - Participatory workshop for } \\
\text { systematical analysis of the situation in the } \\
\text { Arkhangelsk Region using the knowledge } \\
\text { of experts and stakeholders in the context } \\
\text { of forest ecosystems } \\
\text { - Visualization of the situation in } \\
\text { Arkhangelsk by creating a conceptual model } \\
\text { presenting the comprehensive systemic web } \\
\text { of identified and causally } \\
\text { interlinked system elements (Table } 3 \text { ) } \\
\text { - Semi-quantitative evaluation of } \\
\text { contributing factors, threats, and stresses: } \\
\text { Strategic relevance = } \\
\text { Current criticality: Importance } \\
\text { for the vulnerability of biodiversity object } \\
\text { - Scope (geographic extent) } \\
\text { - Severity (intensity of negative impact } \\
\text { on biodiversity within the next } 10 \text { years) } \\
\text { - Irreversibility (degree of permanency } \\
\text { or impermanency) } \\
\text { + Past criticality: The status of } \\
\text { criticality } 20 \text { years ago } \\
\text { + Current trend of change: Tendency } \\
\text { that the current criticality is changing } \\
+ \text { Systemic activity: } \\
\text { infences) }\end{array}$ & $\begin{array}{l}\text { Conceptual model presenting } \\
\text { the situation in the } \\
\text { Arkhangelsk Region which } \\
\text { allows for prioritising most } \\
\text { relevant elements }\end{array}$ \\
\hline
\end{tabular}




\section{Details and content of the ECOSEFFECT methodological steps}

- Number of influenced elements

Manageability: Potential to be influenced

and changed by actors with available resources

Knowledge: Available information and quality of information

- Translation of FSC principles into strategic complexes, FSC criteria into strategies and

3. Strategic interpretation FSC indicators into activities

- Coherency: determination of interrelations between the strategic components within FSC PCI. Expected interplay and dependencies between strategies

4. Leverage points

- Participatory workshop with experts on forests and FSC-certification in Arkhangelsk

- Mapping of sustainability-strategies into the conceptual model

- Determining the direction (positive or

5. Theory of change and secondary risk analysis negative) and intensity (low or high) of the influence (semi-quantitative assessment by experts) (Table 4)

- Reformulation of addressed elements into expected outcomes (direct and indirect results) along postulated results-webs through logically linked assumptions

- Comparing influence of FSC against values of strategic relevance of contributing factors, threats and stresses
Synopsis of strategic measures stipulated by the Russian National FSC Standard

Identification of the locations in the conceptual model where FSC Criteria exert influence
Quantification of influence and postulation of theoretical results

- Identifying elements in the conceptual model which have not been addressed by FSC but were in reach

6. Gap analysis of FSC objectives and rated to be strategically relevant as well as elements that are influenced in a negative way

Identification of (intensified in their potential to induce threats strategic gaps 


\subsection{Ecosystem Diagnostics Analysis}

Ecosystem Diagnostics Analysis (EDA) is the first step in ECOSEFFECT and comprises a desktop assessment of available spatial data combined with quick field visitations of a designated project site or landscape. In the spatial analysis, forest cover and evidence of land cover change were examined as preparation for both the conceptualisation of the situation analysis and a field inspection. Data on annual tree cover loss between 2001 and 2014 [50] was used to look at logging patterns and to calculate tree cover loss before and during FSC certification, as well as in the forest landscape outside of FSC-certified concessions. Maps on the spatial distribution of FSC-certified forest management units (FMU) as of May 2016 [51] were processed, the issue date for each certificate holder was revised according to available certificates [52], and the dataset was clipped with annual tree cover loss [50] using the software ArcGIS [53]. In the spatial analysis, the relative year in relation to the implementation of FSC was computed. In particular, tree cover loss that occurred within a logging concession before it was FSC-certified was classified as "before FSC". Tree cover loss classified as "during FSC" implies that the tree cover was lost while an FSC-certificate was valid. Tree cover loss in the initial and final year of certification as well as tree cover loss after FSC certification (altogether accounting for $12 \%$ of the dataset within FSC concessions) was excluded from the analysis to reduce uncertainty, as it was unclear if that particular moment of tree cover loss was recorded just before or after certification. In addition to the spatial analysis, a visitation to a forest management unit in the Vinogradovskiy district, east of Bereznik (Vaengskiy

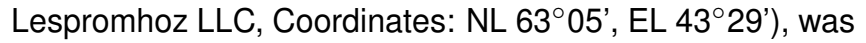
carried out on recently and formerly logged forest areas to verify the available spatial data and to discuss changes to forest structure, hydrology, and soil conditions brought about by harvesting practices with experts in the field.

\subsection{Ecosystem-Based Situation Analysis of Arkhangelsk}

A situation analysis describes the process of systemically collecting available knowledge to assess the conditions within a region of interest, including the vulnerability of biodiversity, and the complex interaction of the main drivers of change. A three-day workshop was launched in June 2014 close to the city of Arkhangelsk to conduct a situation analysis of the Arkhangelsk Region together with 16 experts affiliated to NGOs, FSC, academic research institutions, and timber companies (Table 2).
Together with the findings of the previously conducted EDA, the results of the situation analysis were visualised in a conceptual model presenting a systemic knowledge map depicting causally interlinked factors that are responsible for shaping the actual situation within the scope (Figure 1).

The systemic analysis began with the identification of the main ecosystem types and the fundamentals necessary to maintain full ecological function, the so-called key ecological attributes (KEA). Other information imported into the conceptual model include a list of aspects relating to human well-being, which is supported by ecosystem services provided by functional ecosystems on the one side, and by social services generated by social systems on the other side. Observable and also speculated environmental stresses that represent negative impacts on biodiversity were compiled as well as the contribution and interaction of the different pressures or threats that cause environmental stresses. The respective drivers of threats, called contributing factors, were also incorporated into the conceptual model. After cumulating and arranging all elements comprising the conceptual model (Table 3), the various systemic components were interlinked according to the most logical cause-effect relationships known or assumed by experts participating in the workshop in order to generate a complex and complete picture of the forests and the impacts of human interventions. The key question for this 'backwardmoving' procedure detecting potential causality was "Where does this come from? What are the direct drivers?".

The method described for this form of conceptual modeling relies on repeated revision and refining of the analysis by the stakeholders participating in the process based on their knowledge and assumptions, until the best possible representation of the situation is achieved. In order to determine those elements in the system that contribute most to the overall vulnerability of biodiversity, the strategic relevance of contributing factors, threats, and stresses was semi-quantitatively evaluated by the workshop participants. It presents a cumulative measure comprising criticality (including geographical scope, severity of impact, and irreversibility), dynamics (e.g., trend of change, expected future criticality), and systemic activity (in- and outgoing influence) (Table 3) applying the MARISCO rating scheme [45].

Elements rated as being highly relevant are those that should be prioritized by FSC to initiate targeted mitigation strategies and action to restore and safeguard the function of the forest environment in the long-term. The situation analysis provides the fundament for the further analysis and represents the situation of forests without FSC certification. 
Table 2. Number of experts and affiliated institutions that participated in the two ECOSEFFECT-workshops.

Institution

Number of participants

Workshop 2014 Workshop 2015

WWF Russia

3

2

Researcher

- Northern Arctic Federal University named after M.V. Lomonosov

2

- Institute of Zoology, Russian Academy of Science

1

1

- Saint Petersburg Research Institute of Forestry

1

Forest company (2)

3

1

FSC Russia

- Russian National Office

1

2

- Technical Committee of FSC National working group

1

FSC International

1

1

Arkhangelsk conservation initiative

1

Certification body

2

Total number of participants

16

7

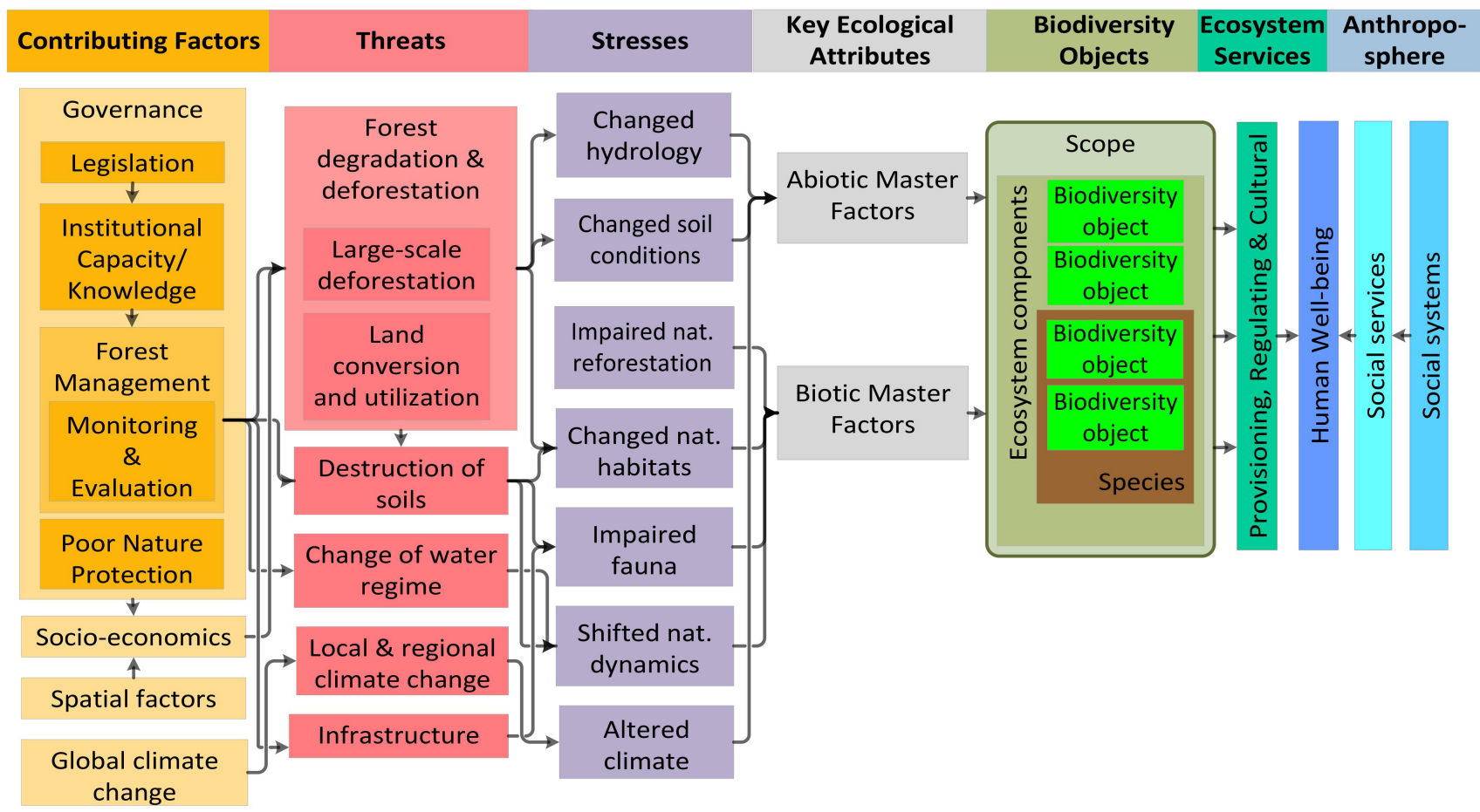

Figure 1. Generalized conceptual model with causally interlinked elements (definitions given in Table 3): Contributing factors are the drivers of threats, which in turn provoke environmental stresses that degrade the key functional requirements of the ecosystems and the provision of ecosystem services essential to human well-being (left to right). Social systems provide social services that contribute to human well-being (right to left). 
Table 3. Definition of elements comprising the conceptual model determined during the situation analysis.

\begin{tabular}{ll}
\hline Element & \\
\hline Social system & $\begin{array}{l}\text { Governmental and non-governmental institutions, business, religious groups, private } \\
\text { organisations and any other group of organized individuals as well as their interaction. }\end{array}$ \\
Social services & $\begin{array}{l}\text { Provided by social systems and can relate to directly applied social benefits as well } \\
\text { as the organization and administration of ecosystem services. } \\
\text { Several human dimensions including subjective and objective factors such as human } \\
\text { Human well-being }\end{array}$ \\
health, quality of life, life satisfaction, and freedom of opportunity. Depending on \\
ecosystem and social services.
\end{tabular}

\subsection{Strategic Interpretation of FSC}

The $\mathrm{PCl}$ of the Forest Stewardship Council Standard for the Russian Federation (FSC code: FSC-STD-RUS-V61-2012 Russia Natural and Plantations EN, Version 6$01,2012-F S C$ in the following) were strategically interpreted by classifying the 10 principles of FSC as strategic complexes that encompass a group of strategies related to a distinct thematic realm. The 56 FSC criteria were understood as strategies that are a set of activities or measures designed to deliver desirable goals and objectives. Indicators of each criterion were interpreted as activities describing specific actions or series of decisions related to a certain strategy.

\subsection{Leverage Points}

In complex systems, such as ecosystems or societies, leverage points represent those locations where small interventions can induce crucial changes [54]. In this study they present points in the conceptual model where FSC criteria apply. At this point, at least one activity of a strategy addresses a specific factor and influences it in such a way as to generate one or more outcomes. The leverage points of FSC were determined by seven experts made up of representatives of WWF Russia, FSC Russia and FSC International, the Northern (Arctic) Federal University of Arkhangelsk as well as one timber company working on the conceptual model during a three-day workshop organized in April 2015 (Table 2, Figure 2). 


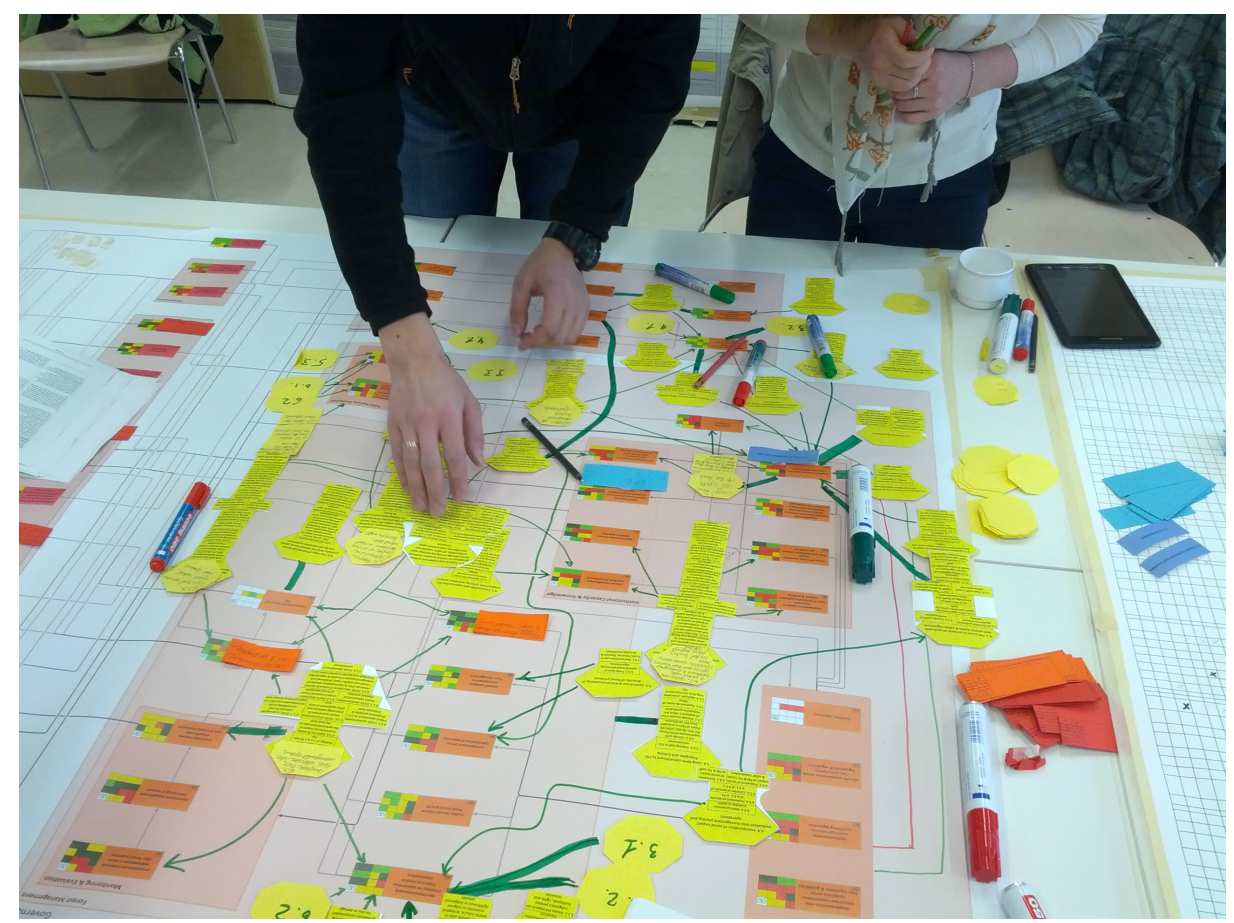

Figure 2. Experts identify the leverage points and influence (green and red arrows) of the Russian National FSC standard (yellow hexagons) and map it against contributing factors (orange boxes) in the conceptual model that illustrates the causally interlinked elements responsible for the situation in Arkhangelsk.

In the same workshop experts postulated and semiquantitatively evaluated the influence of FSC. The nature of influence of a particular strategy depends on the sufficiency, adequacy, and accuracy of activities in addressing the targeted problem or contributing factor. Whilst FSC is expected to induce positive outcomes in the environment, there remains the risk of exacerbating factors, threats, and stresses if associated strategies are found to be detrimental. Four possible scores were disseminated representing the direction and intensity of influence and ranging from one (strong and negative influence) to four (strong and positive influence) (Table 4).

\subsection{Theory of Change}

The theory of change describes a process of predetermining the outcomes derived from the influence of FSC on the causally interlinked elements collected in the conceptual model. The direct influence and positive transformation of factors induced by FSC can potentially trigger a cascade of responses leading to a mitigation of anthropogenic threats and the alleviation of environmental stresses. The reformulation of contributing factors, threats and stresses was conducted in the second workshop by participating experts according to their best knowledge, by experience, and logical assumptions.

\subsection{Gap Analysis}

In a gap analysis, those elements in the conceptual model that remain unaddressed by $\mathrm{FSC}$ as well as $\mathrm{PCl}$, that do not apply to the situation in the Arkhangelsk Region, were identified. Any contributing factor, threat, and environmental stress unaddressed or intensified by a strategy could potentially jeopardize the effectiveness of the certification system in achieving its ecological objectives. Potential limitations of FSC have been identified and recommendations for improving the certification system and its effectiveness were developed. This step takes into account the scope of FSC in the Arkhangelsk Region that was delineated by discussing the effective range of influence of the standard with focus on forest ecosystem management with experts.

Table 4. The four possible scores for influence refer to the direction and intensity of a strategy: positive influence creates opportunities; negative influence intensifies the negativity of a factor or impairs existing opportunities; strong influence results from targeting factors precisely; weak influence refers to addressing factors only partially.

\begin{tabular}{cccc}
\hline \multicolumn{2}{c}{ Influence } & \multicolumn{2}{c}{ Intensity } \\
& & Strong & Weak \\
\hline \multirow{2}{*}{ Direction } & $\begin{array}{l}\text { Positive } \\
\text { Negative }\end{array}$ & $4=$ Strong and positive & $3=$ Weak and positive \\
& Ne Stong and negative & $2=$ Weak and negative \\
\hline
\end{tabular}




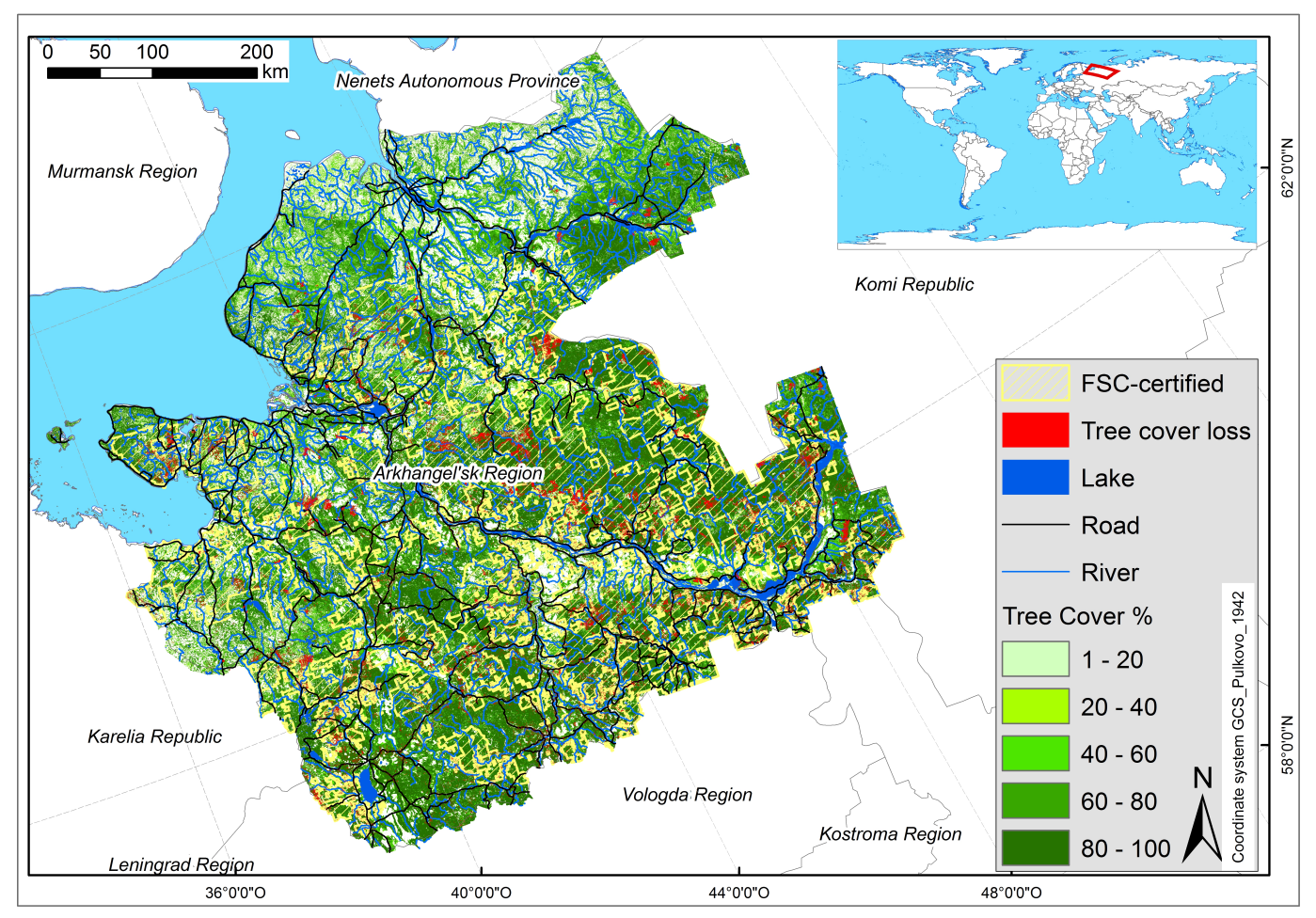

Figure 3. Map showing the Arkhangelsk Region and tree cover as of 2000 and tree cover loss between 2000 and 2014 [50], FSC-certified areas [51], and the network of lakes, rivers, and roads [55].

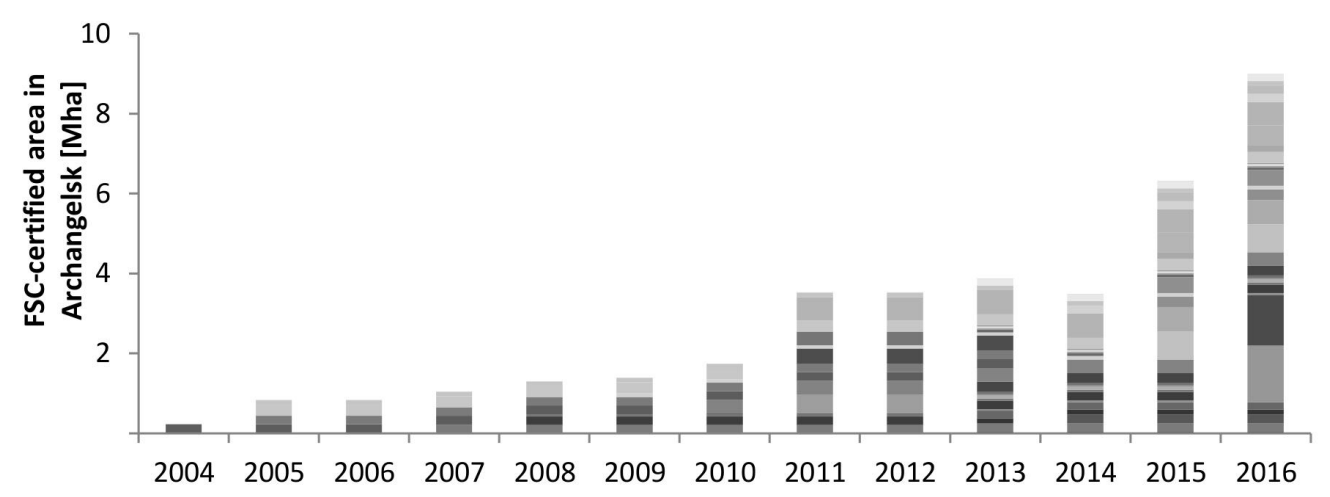

Figure 4. Spatial coverage of FSC-certified timber companies in the Arkhangelsk Region between the beginning of its implementation in 2004 until 2016 [52]. Different levels of grey represent each of the 41 FSC-certified companies. 


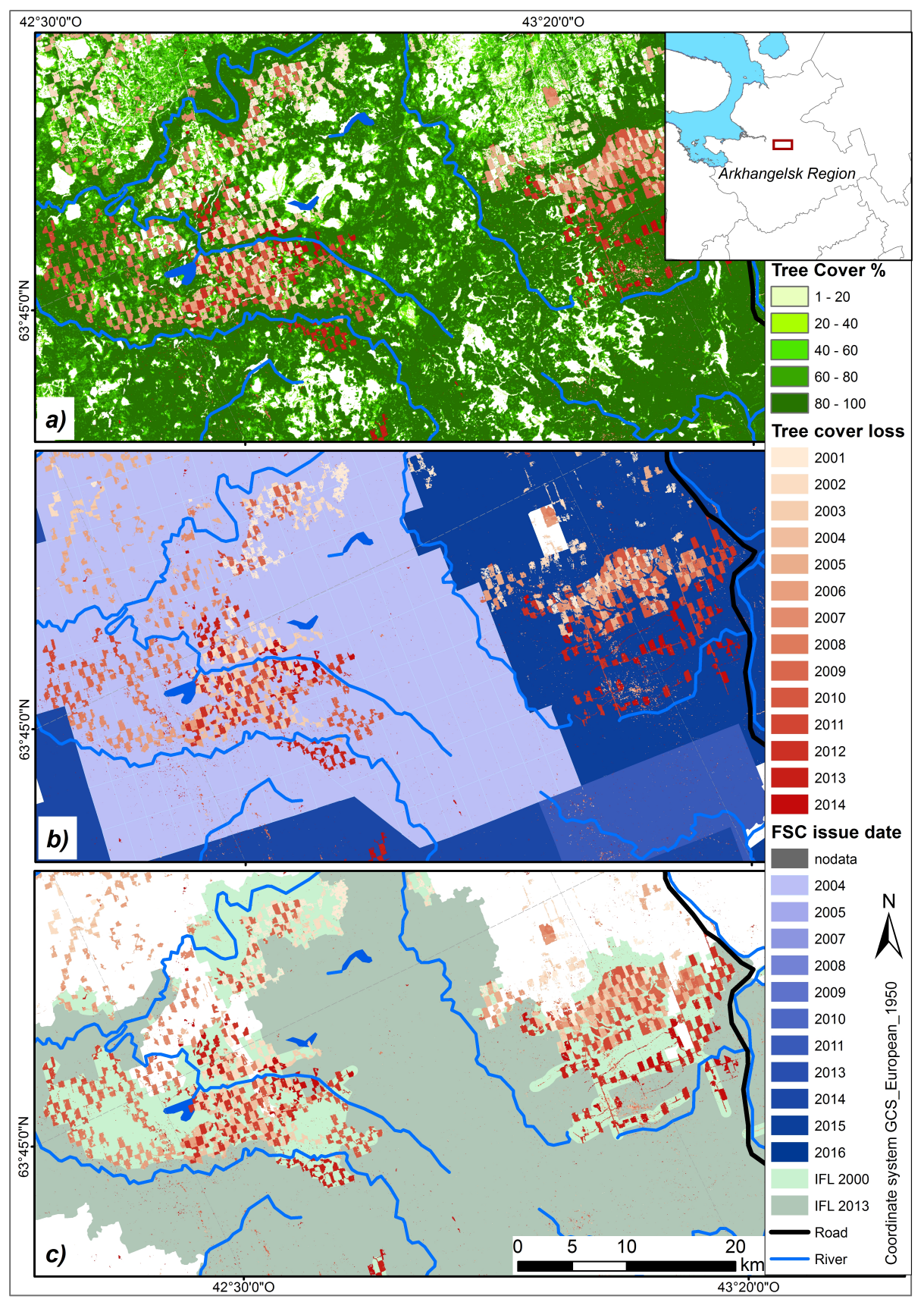

Figure 5. Forest, forestry and FSC certification within an example area in the centre of the Arkhangelsk Region: a) tree cover (light to dark green) is being reduced by consecutive geometric clear-cuts(light to dark red) [50]; b) tree cover loss patterns before and during valid FSC certification (colours from light to dark blue indicates the issue date of FSC certification) [50,51]; c) annual tree cover loss has reduced the extent of intact forest landscapes (IFL) [32]. Other visible data includes roads and rivers [55].

\section{Results}

\subsection{Ecosystem Diagnostics Analysis}

The Arkhangelsk Region comprises an area of around 31 million hectares of which almost half is classified as forest (as of 2000) [50]. The complex ecosystem mosaic of forests, rivers and mires is fragmented by roads. Large tracts of managed forest are under FSC certification (Figure 3).

The implementation of FSC in the Arkhangelsk Region first started in 2004 with the certification of two companies encompassing around 235 thousand hectares. FSC-certified areas have been increasing up to more than 9 million hectares, leased under 41 different companies in 2016 (Figure 4).

Over the years commercial logging has reshaped the natural boreal forest ecosystem into a patchwork of 
checkerboard-like patterns created by systematic geometric clear-cutting (Figure 5a).

The clear-cuts appear as geometrical rectangles, and forest roads become visible as straight lines of tree cover loss, whereas larger irregular patches of tree cover loss are most likely burnt sites, but could also be the results of deforestation for mining activities. Due to the inaccessibility of remote forest areas and the absence of local population, the small and diffuse patches of tree cover loss were not referred to logging but classified as forest die-back. Examples of die-back, particularly in spruce forest, were noticed in unmanaged stands during field-trips in the neighborhood of clear-cuts. Across most of the study area, the systematic harvesting of timber brought about a distinctive 'checkerboard'-pattern that has been steadily increasing both within and outside FSC-certified areas. The consecutive, year-by-year clear-cuts add up to larger continuous clear-cuts without any substantial remain- ing tree cover that can be several square kilometers across (Figure 5b). Legal logging activities, also in FSC-certified logging concessions, have contributed to a considerable decrease in the extent of IFL in 2013 in comparison to 2000 and logging patterns in the example area show how the remaining IFL has been shrinking in recent years and how formerly continuous tracts of forest are now fragmented and can be prone to tree dieback (Figure $5 \mathrm{c}$ ).

Between 2000 and 2014, almost one million hectares of forest in the Arkhangelsk Region were affected by tree cover loss, of which more than half was recorded within the concessions that were already FSC-certified or had acquired certification during this period (Figure 6).

Tree cover loss was detected in $5.35 \%$ of the total area held by companies that have been or are in the process of certification compared with $2.44 \%$ of forest that has never been under FSC-certification (Table 5).

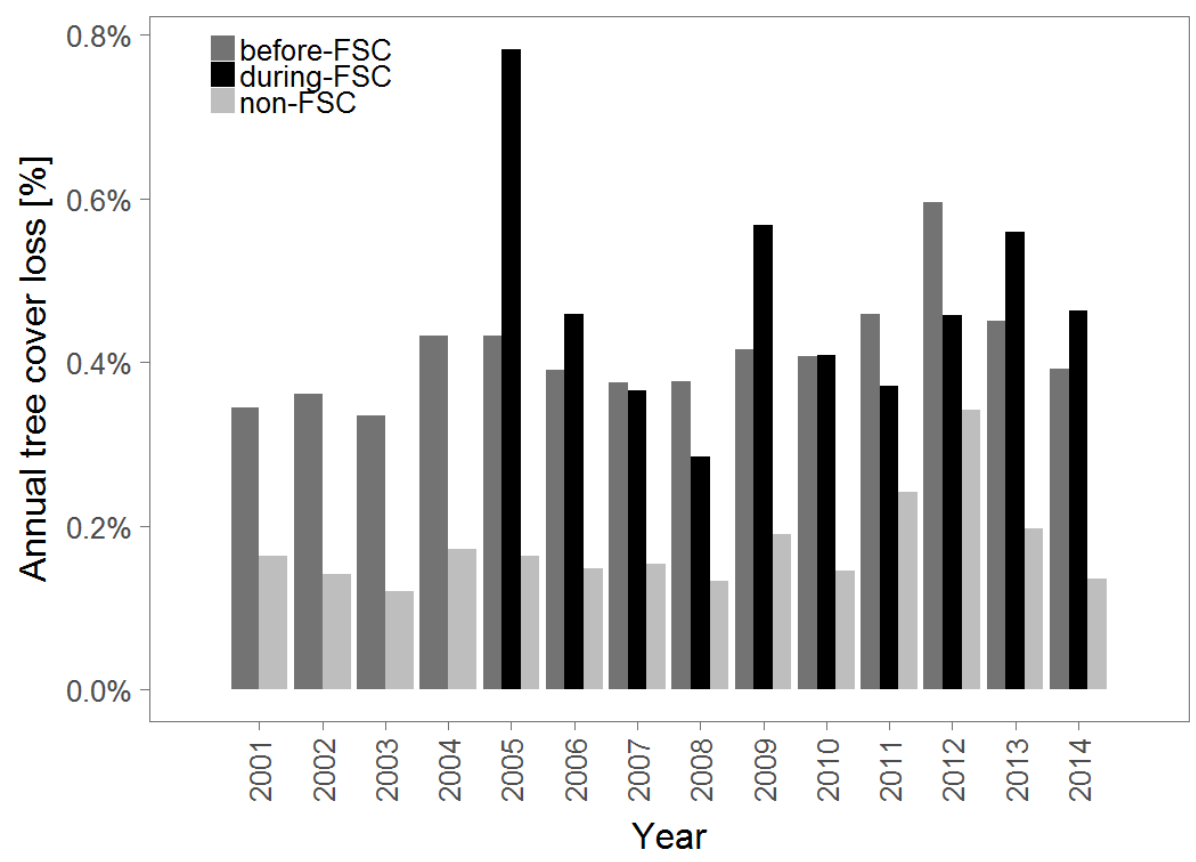

Figure 6. Annual tree cover loss between 2001 and 2014 [50] within and outside of FSC-certified areas in the Arkhangelsk Region. 'Before-FSC' refers to concessions where tree cover loss occurred before FSC-certificates were issued; 'duringFSC' indicates tree cover loss that happened while FSC-certificates were valid; non-FSC covers areas for which no FSC-certificates were available throughout this period.

Table 5. Tree cover loss inside (before-FSC: before FSC certification was issued; during-FSC: while FSC certification was valid) and outside (non-FSC) of FSC-certified logging concessions.

\begin{tabular}{lcccccc}
\hline & $\begin{array}{c}\text { Mean size of } \\
\text { tree cover loss } \\
\text { polygons [ha] }\end{array}$ & $\begin{array}{c}\text { Maximum size of } \\
\text { tree cover loss } \\
\text { polygons [ha] }\end{array}$ & $\begin{array}{c}\text { Sum of tree } \\
\text { cover loss [ha] }\end{array}$ & $\begin{array}{c}\text { Mean annual } \\
\text { tree cover loss [\%] }\end{array}$ & $\begin{array}{c}\text { Amount of tree } \\
\text { cover loss } \\
\text { polygons }\end{array}$ & $\begin{array}{c}\text { Total spatial } \\
\text { coverage [ha] }\end{array}$ \\
\hline before-FSC & 1.2 & 2701 & 431883 & 0.41 & 361083 & 9358863 \\
during-FSC & 1.28 & 1131 & 68353 & 0.47 & 53554 & 645889 \\
non-FSC & 0.75 & 4554 & 483649 & 0.17 & 19790859 \\
\hline
\end{tabular}




\subsection{Ecosystem-Based Situation Analysis with Experts}

The set of causally interrelated elements representing the situation in the Arkhangelsk Region were identified during the expert workshops and illustrated in a conceptual model (Annex 1). The ecosystem complex 'taiga of Arkhangelsk' is determined to be an umbrella biodiversity object encompassing 27 nested biodiversity objects. The nested objects include key species of flora and fauna within the three interacting sub-ecosystems forests, mires (ombrotrophic and mineralotrophic), and aquatic ecosystems. The diverse mosaic of forest ecosystems comprises spruce forest, aspen forest, broad-leafed forest, karst forest, dune forest, herbrich forests and riparian forests, and supports important fauna, including soil biota as well as aquatic and semiaquatic organisms.

The workshop participants described 21 regulating, provisioning, and cultural ecosystem services that contribute to 11 objects of human well-being classified under: health, security, materials for living, and social relationships.

The Key Ecological Attributes (KEA) consist of 11 abiotic factors relating to energy, humidity, lithosphere, wind, and temperature together with 23 biotic factors classified broadly under three categories: biomass (living and dead), information (genetic information), and networks (structures and interrelations). Biotic and abiotic factors, but particularly those attributes relating to networks and information, are found to be affected by human-induced disturbances. The lithosphere and the hydrological regime would also be impacted, but in general, abiotic KEA are considered to be less affected by the identified stresses than biotic ones.

A total of 38 contributing factors (Annex 2) cause 20 threats (Annex 3 ) and are believed to be responsible for inducing 32 stresses (Annex 4) in the Arkhangelsk Region.

\subsection{Rating of Stresses, Threats, and Contributing Factors}

The semi-quantitative evaluation of stresses, threats, and contributing factors by experts and stakeholders suggests that all identified and rated contributing factors are important or extremely important in increasing the overall vulnerability of the conservation objects, which is represented by high values of 'criticality'. Contributing factors relating to governance and socio-economics, forest management, institutional capacity and knowledge as well as nature protection are assumed to be the major and persistent drivers of negative changes in the taiga of the Arkhangelsk Region. The threats that are rated highest for criticality are linked to problems of "Deforestation and forest degradation", "Infrastructure within the forest", the "Construction of non-forest roads", and "Extreme weather events". The problem of large-scale clear-cuts ("Too big size of clear-cut"), which in turn links up to "Harvesting in HCVF, including intact forests", and "Forest infrastructure" is recorded as highly critical to the long-term security of biodiversity.

One third of all identified stresses are considered to be very critical symptoms of negative impacts. In particular, "Contamination of surface and underground water", "Decrease of natural forest regeneration", "Dissociation of populations - gene flow", "Change of forest age distribution less very old trees", "More homogenous and contrast spatial structure", "Diversity of forest ecosystem is reduced", "Number of habitat is reduced", "Vulnerable species extinction", "Change of wood species - changed cycles", and "Changed routes of animal migration" are rated as extremely important stresses.

Most of the rated elements are estimated to be moderately relevant. Apart from three contributing factors, none of the other factors, threats or stresses is rated as being highly relevant. Almost one fourth of all the contributing factors and less than one third of threats are recorded as being highly relevant (Figure 7).

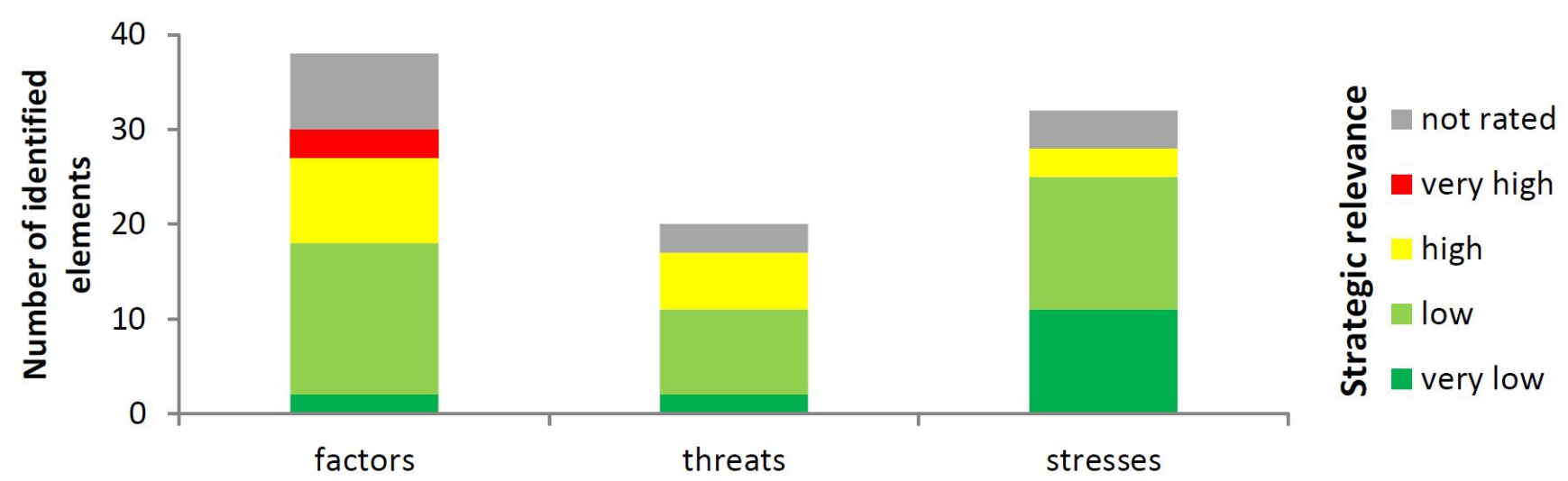

Figure 7. Distribution of values of strategic relevance rated for identified contributing factors, threats, and stresses. 
The three most strategically relevant contributing factors identified in the workshop are linked to governance and include "Too many norms, legislations \& regulations", "Poor legislation \& guidelines" as well as the institutional factor "Lack of long-term multipurpose planning". This suggests ambiguous and contradictory legal instruments and governance, together with insufficient specifications, hamper the effective implementation of ecologically relevant legislations. The strategically most relevant threats refer to large-scale forest degradation, infrastructure, landform configuration, and climate change. Changes to the natural structure and character of habitats are considered to be the most strategically relevant stresses including "More homogenous and contrast spatial structure", "Diversity of forest ecosystem is reduced", and "Number of habitat is reduced". The stated causes of natural habitat destruction given by the participants are manifold; the most important ones relate to forest management practices and the need for accessibility by roads.

\subsection{Systemic Analysis of FSC Strategies}

According to the experts and stakeholders, FSC strategies target more than $75 \%$ of all identified contributing factors directly. Most of the contributing factors are addressed only once, but several strategies refer to the same contributing factor several times (Figure 8).

In total, 104 points in the conceptual model are leveraged on 29 different contributing factors by 39 different strategies. Two contributing factors, namely "Poor law enforcement" and "Failure to involve stakeholders", are tar- geted most often and addressed by 11 different strategies. The estimated influence of the strategies ranges from weak and negative to strong and positive, whilst most strategies appear to influence contributing factors in a weak and positive way (Figure 9).

All contributing factors that are rated as being highly and very highly strategically relevant are addressed by FSC, whereas the two strategically relevant contributing factors "Inadequate government control (of nature use)" and "Mining", as well as the two strategically less relevant factors "Wish to make quick money" and "Violations of technological regulations", are understandably not covered by FSC (Figure 10).

Most of the strategies derived from the FSC criteria are assumed to target one or several of the contributing factors. A total of 17 strategies (including nine based on criteria describing principle 10: "Plantations") do not target any of the threats or contributing factors in the conceptual model. Some of the strategies are seen to relate more often to certain contributing factors than others. For example, criterion 1.6 ("Long-term commitment to FSC Principles and Criteria") is mapped most frequently and leveraged 11 factors. Three criteria, criterion 1.1 ("Respect all national \& local laws and administrative requirements"), criterion 6.1 ("Complete Environmental Impact Assessment and integrate into management"), and criterion 6.2 ("Safeguards to protect rare, threatened and endangered species and their habitats; establish conservation zones and protection areas; control inappropriate hunting, fishing, trapping and collecting"), are referred to seven different contributing factors (Figure 11).

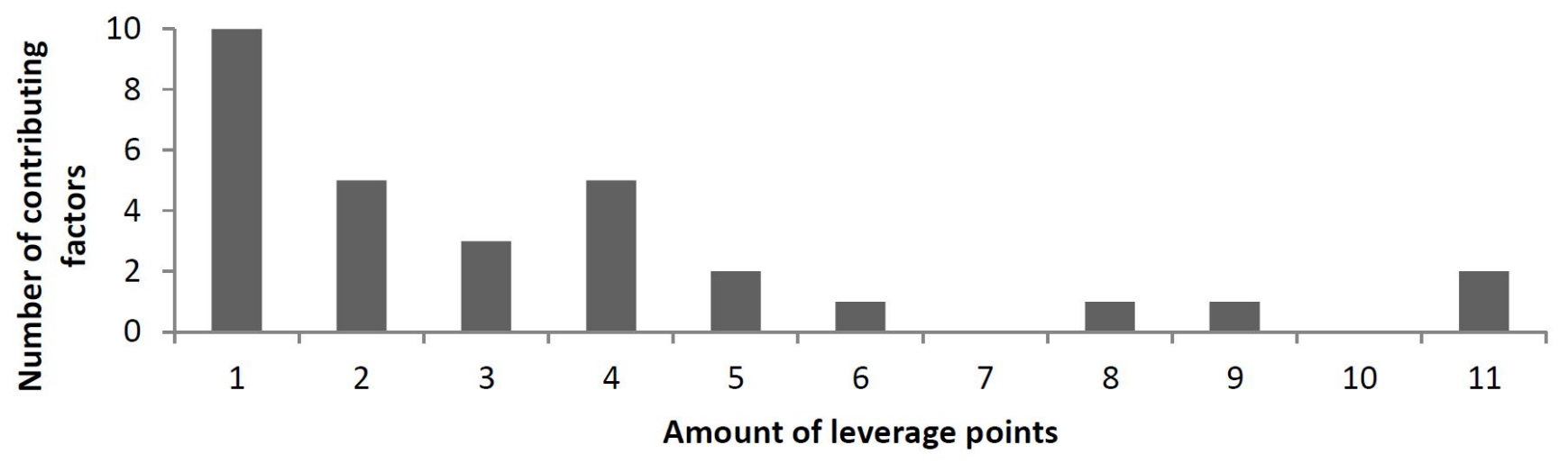

Figure 8. Frequency of leverage points: Number of counts contributing factors targeted by FSC strategies. 


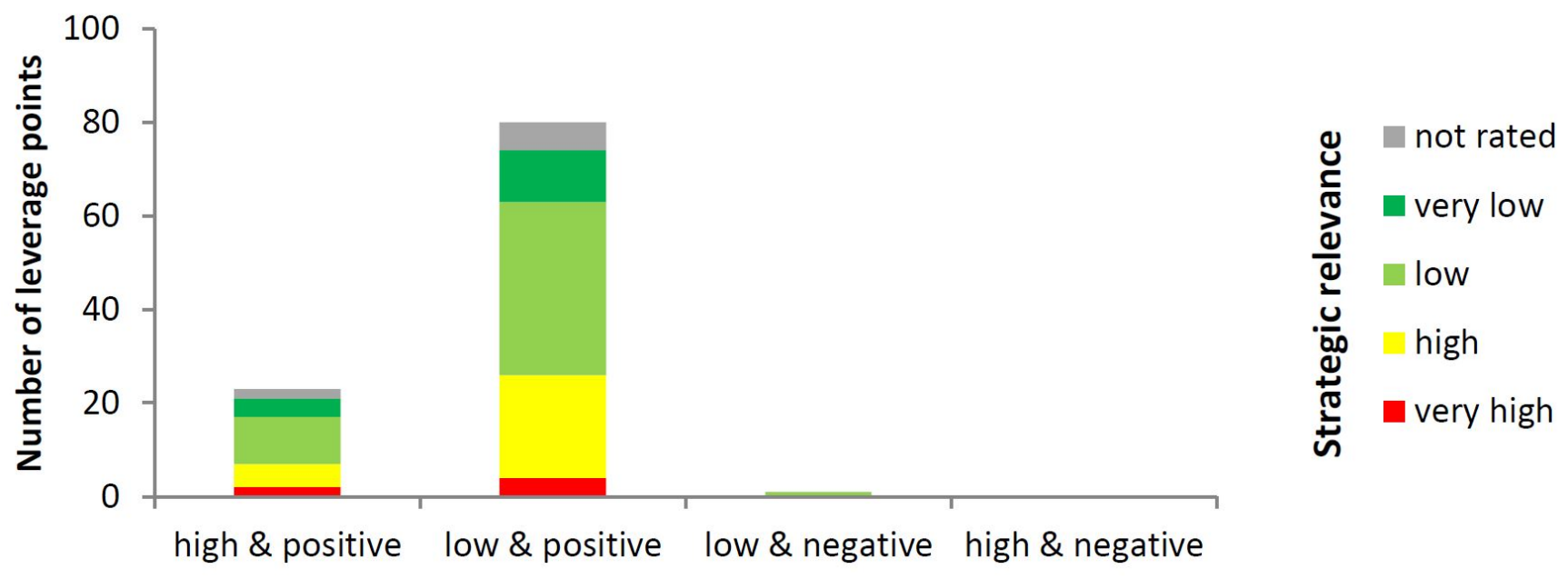

Influence

Figure 9. Distribution of strategic relevance of factors that are influenced by FSC strategies.

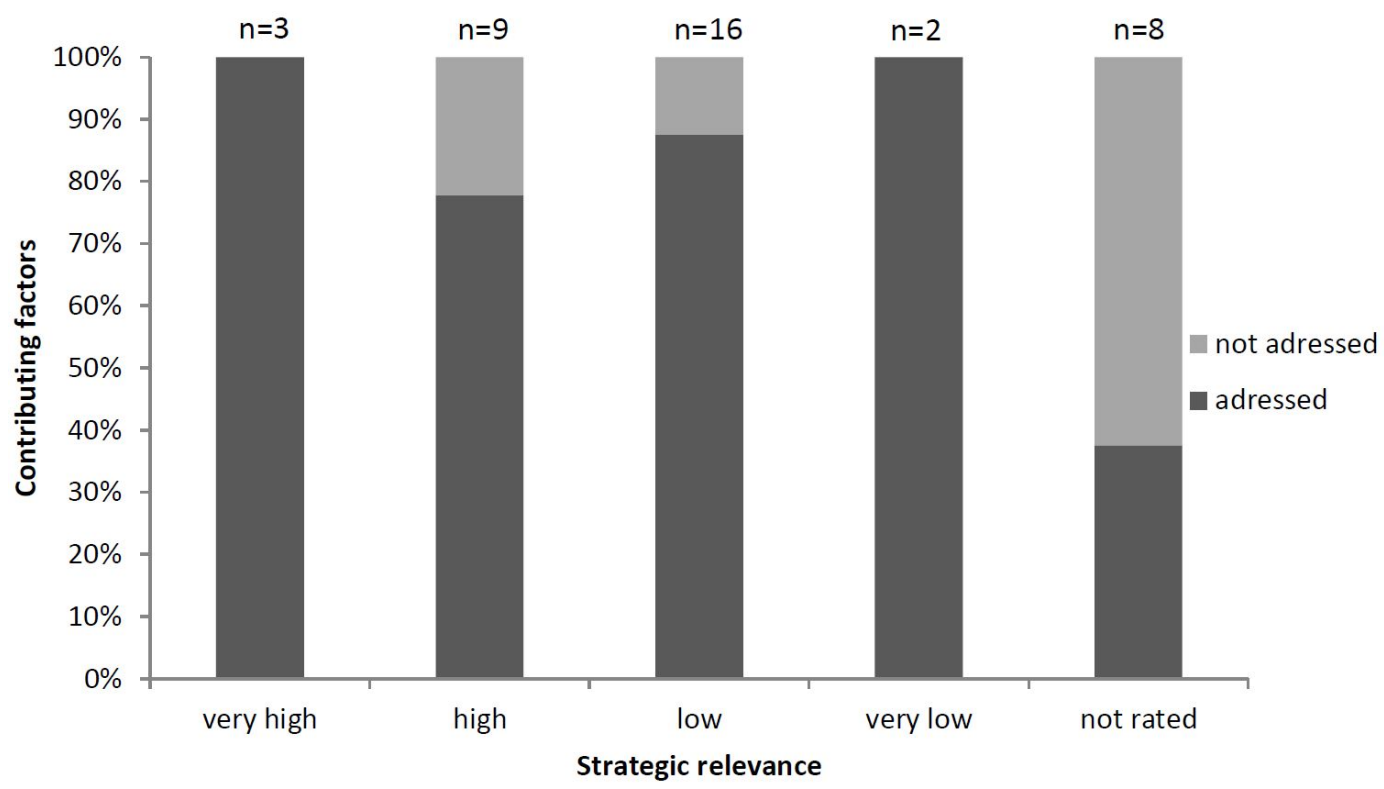

Figure 10. Contributing factors addressed directly by FSC and categorized according to their strategic relevance $(1=$ low, 4 = high). 


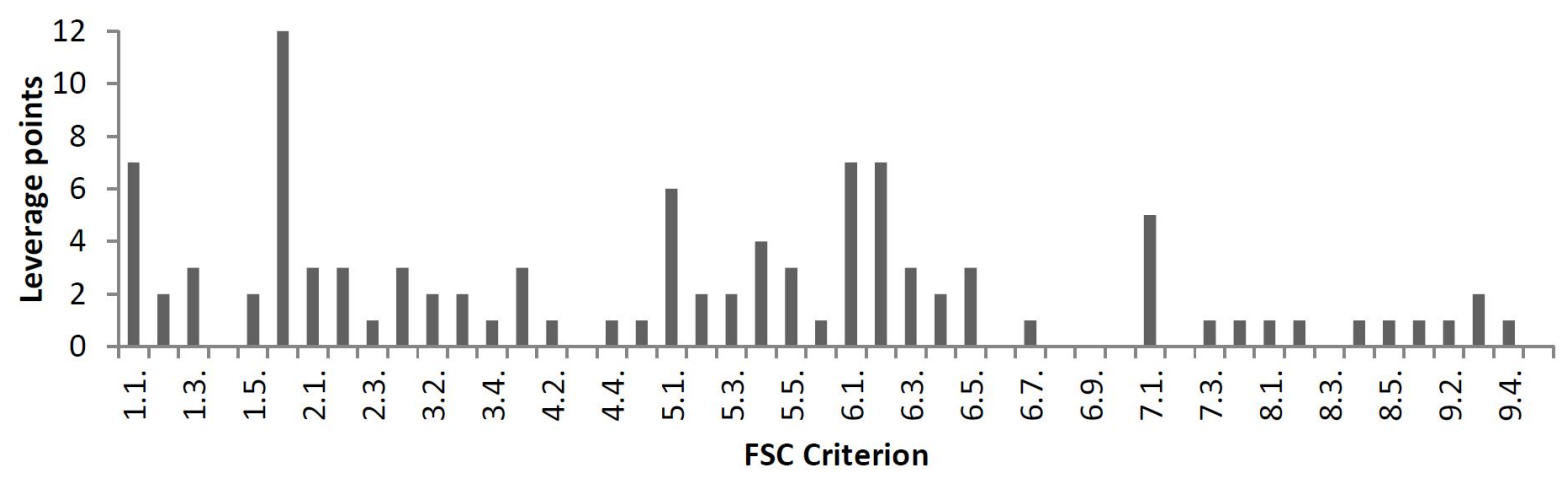

Figure 11. Histogram showing each of the FSC criteria and the frequency being referred to different contributing factors that were identified during the situation analysis.

\subsection{Theory of Change}

The following paragraphs present the results for the assessment of the potential outcomes of action triggered by FSC certification according to the postulated theory change (Annex 5). The scope of certification embraces the total leased area rather than including just selected sites. Consequently, all potential outcomes would have to apply to all FSC-certified logging concessions.

Within the group of contributing factors linked to governance, FSC criterion 1.1 targets each of the contributing factors relating to legislation in a positive but weak way. In theory, the negative influence attributed to strategically relevant ineffective norms and the current legislation relating to forests and forestry are supposed to be reduced. The strategically relevant factor "Corruption" is considered to be reduced by the weak but positive influence of three different FSC criteria designed to enhance the documentation of legislative requirements and long-term land-use rights. Theoretically, FSC would lead to the provision of effective and clear legislation for responsible forest management, based on the given guidelines for road and bridge construction, and the contribution to a more stringent enforcement of administrative regulations. Illegal activities, including illegal logging, are assumed to be prevented under FSC. The rights, as well as all health and safety requirements of workers are believed to be respected. All kinds of applicable payments are supposed to be documented and promptly paid. The attendance by staff on training in the proper implementation of FSC and on forest management planning would, hypothetically enhance their level of knowledge, expertise, and proficiency. The expectation would be for clear and obvious compliance with laws and international treaties ratified by the Russian Federation.

According to the experts, all factors relating to forest management would be directly influenced by various FSC criteria. As a possible outcome, the management objectives of a certified company would be defined in the long-term, at least for a minimum of five years. Poor forest management is expected to improve in certified forest companies by amending the forest management plans according to the findings of an Environmental Impact Assessment (EIA). In theory, the EIA would be conducted and a forest monitoring system would be established according to the guidelines anchored in the FSC standard. Moreover, it is assumed an economic analysis would be conducted and the findings incorporated into the forest management plan. A monitoring program is supposed to be established, being clearly documented, consistent, replicable, and regularly revised by the FSC-certified forest companies. Deviations from the management plan and discrepancies between actual and expected results would be assessed and considered in the revision of the management plan. It is presumed that transparency would be enhanced through the publication of management documents and monitoring results for certified companies, except in cases where confidentiality is required. Consequently, the quality of available information would be enhanced, including environmental, economic, and social aspects of forestry as well as improved access to information on natural resources for planning purposes. In addition, FSC is expected to deliver improvements in the availability of data on yields, growth rates, forest composition, regeneration, and changes in the composition of flora and fauna.

The analysis concludes that FSC would lead to a reduction of logging in primary or old-growth forests. In theory, FSC requires HCVF areas to be identified and considered in the planning and the implementation process of forest management operations. Stakeholders, such as local people, authorities, administrations, and forest managers would be technically consulted, especially in the frame of a social impact analysis. Land-use rights for indigenous people and their access to natural resources are requirements for companies operating under FSC. The interests of local communities extend to unrestricted access to timber and non-timber forest resources. In principle, the $\mathrm{FSC} \mathrm{PCl}$ are designed to reduce the risk of disputes and grievances between local communities and commercial companies, and in part, this is achieved through an anticipated enhancement in environmental and social awareness amongst forest workers and staff by providing training, and by employing predominantly local people with strong concerns for the 
forest and its natural resources.

In theory, the planning and implementation of forest management under FSC takes into account international treaties as well as conventions on biodiversity conservation and protected areas. For example, the identification, monitoring, and protection of rare, threatened and endangered species, key habitats, and HCVF would be developed by researchers and in consultation with specialists and other stakeholders, and then implemented by the certified company. Thus, in theory, it is assumed that HCVF and undisturbed areas would be protected from forestry activities and buffer zones would be established around sensitive sites. Under FSC, water protection zones would be maintained and riparian areas that have been degraded by forest operations would be restored. Moreover, a network of representative examples of existing ecosystems is supposed to be established and management restrictions observed. The effectiveness of conservation measures on HCVF would be assessed annually by the certified company. Participants assume that under FSC, the annual allowable cut (AAC) is calculated sustainably. Forest operations would take account of economically inaccessible regions and areas where logging is restricted, such as in HCVF. The rationale for the calculation of $A A C$ and planned harvesting level is expected to be provided in the management plan of FSC-certified logging companies. The financial resources needed to implement the forest management plan would be available at certified companies. As a potential result, it is postulated that forest management would be conducted according to the management plan and any negative environmental impacts due to forest operations described as "cut-and-go practice" are reduced.

FSC promotes the use of all merchantable woody resources and the diversification of utilized and processed forest products. Thus, it is assumed that a FSC-certified forest company would optimize their expenses by an effective economic analysis being incorporated into the management plan. Data on costs, productivity, and efficiency of the forest management are supposed to be collected and analyzed by FSC-certified forest companies. This is expected to result in high profitability and economic sustainability that would also contribute to stabilizing the local economy. As a theoretical result, income opportunities for the local population are enhanced by getting the chance of an employment in the forestry sector and the possibility to increase incomes of forest workers by negotiating with their employers. The illegal use of natural resources would be banned under FSC.

The changes to contributing factors by FSC are assumed to initiate a strong and positive influence on $45 \%$, and a weak and positive influence on $30 \%$, of the identified threats. All of the strategically least relevant threats are anticipated to have a stong influence in a positive way (Figure 12).

Half of the threats believed by the participants to be strategically relevant, in theory, are, likely to be influenced by FSC in a weak and positive way, whilst $17 \%$ are consid- ered to be effected in a strong and positive way. For each of the targeted threats, threat-reduction-results are formulated (Annex 6). Only one of the threats, namely "Gathering of forest litter", is assumed to be negatively influenced due to the diversification and optimal use of forest that increases the collection of forest residues. A strong and positive influence is postulated for $60 \%$ of the identified threats. The strong and positive influence of FSC is assumed to mitigate all identified threats leading to large-scale tree cover loss. In theory, the strong positive influence of FSC would reduce the size of clear-cut patches and also decrease the percentage of clear-cuttings, prevent logging in HCVF, reduce the deterioration of soil quality, avert the change of soil composition and hydro melioration, lower the excess of allowed cut during selective logging, induce selective logging without damaging trees, and foster a more sustainable use of nontimber forest products. Potentially, the identified negative impacts of infrastructure on the forest ecosystem induced by the construction of new roads and bridges would be slightly reduced. Moreover, the weak and positive influence of FSC requirements would reduce the overexploitation of timber resources and encourage negotiations as well as agreements between the certified forest company and communities about the location of pastures. Moreover, changes in the hydrological regime are supposed to be avoided, and water quality would be maintained.

The anticipated reduction of perceived threats to the forest environment is estimated to reduce almost half of all identified stresses (Annex 7). Most of the stresses are anticipated to be moderately reduced. The three most relevant stresses are expected to be influenced in a weak and positive way (Figure 13).

One single potential stress-reduction result, namely " $R e$ duced anthropogenic forest fires", being rated as less strategically relevant, is transformed through a strong positive influence of FSC. The presumed reduction of tree cover loss in HCVF, key habitats, and representative samples of ecosystems would contribute to a loss of habitat for forest-dwelling species in general, but forest operations and habitat degradation would continue elsewhere within the concession.

FSC certification does not specifically require the restoration of degraded forests. The homogeneity and loss of forest diversity are assumed to be reduced by the promotion of smaller and fewer clear-cuts, and retaining mature and old trees in primary forests under the FSC regime. The potential for regeneration in logged forests is supposed to be improved by supporting natural rejuvenation and retention of seed-trees. The extinction of vulnerable species and the disturbance of forest fauna would be possibly reduced where rare, threatened and endangered species and their habitats are identified and where protection or restoration measures are implemented. The intensity of flooding is supposed to be reduced by retaining or restoring riparian vegetation. The quality of water would improve thanks to reduced pollution after FSC-certification. 


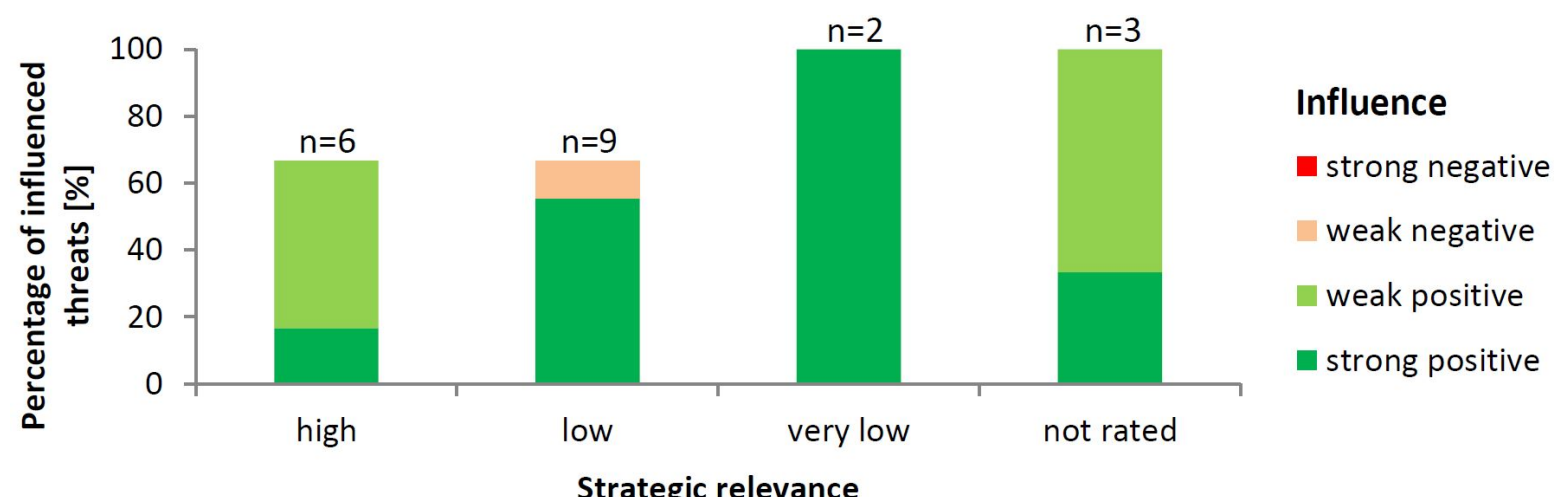

Figure 12. Influence of FSC strategies on described threats categorized according to their strategic relevance.

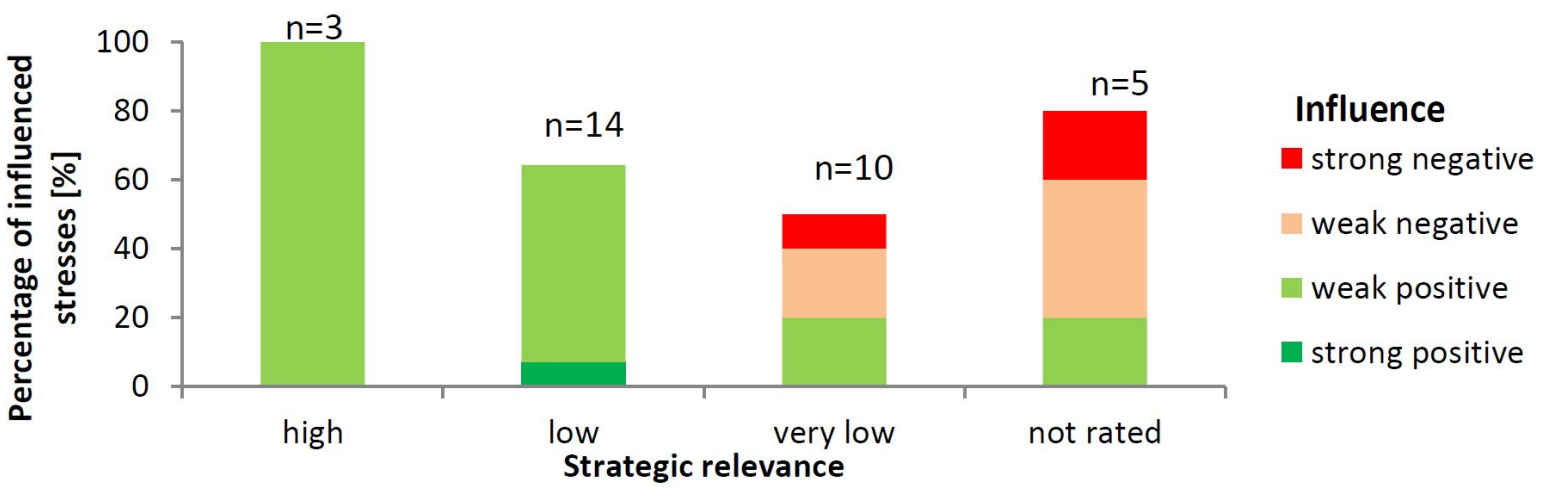

Figure 13. Influence of FSC strategies on stresses of different strategic relevance.

\subsection{Gap Analysis}

Four of the identified contributing factors are assumed to be out of the scope of FSC. In particular, "Mining", "Agricultural activities", "Global human population growth", and "c "Increasing global resource demand" are neither directly nor indirectly related to forest management. Those contributing factors are not directly manageable by applying forest management strategies and are not addressed by the PCI. All identified threats, apart from the climate change related threat "Extreme weather events", are supposed to be impacted by forest management operations and could potentially be strategically influenced by forest certification.

The gap analysis revealed that "Inadequate government control (of nature use)" and the introduction of exotic fauna, together with the disruptions they can cause to forest ecosystems, as well as "Overhunting" of animals (except for those species identified as rare, threatened or endangered) would remain unaddressed by FSC. FSC targets the negative impacts of infrastructure construction and the reduction of negative impacts of existing infrastructure on biodiversity, but only inside designated IFL.

FSC does not address forest fragmentation and isolation outside IFL and HCVF, including areas that are voluntarily spared from felling, inaccessible or unprofitable for timber extraction. According to the Russian FSC standard, timberlogging companies are not required to alter the systematic and extensive felling of trees according to the prevailing 'checkerboard system'. Large-scale forest degradation is likely to continue unless there is active conservation planning to establish wildlife corridors at a scale appropriate for the needs of large mammals such as elk, bear, wolf and wild reindeer. Continuing with current practices in forest management, even under FSC certification, is predicted to disadvantage large mammal populations and to contribute further to ecosystem degradation. Changes in the migration routes of the larger mammals are addressed indirectly by FSC through the specifications for HCVF, representative ecosystems, and through ecological networks.

All criteria and indicators associated with principle 10 ("Plantations") do not apply to the situation analysis, as all forestry in Arkhangelsk Oblast is carried out in primary and secondary forest landscapes. In the situation analysis, the conventional forest management scenario is described with no reference to potential conflicts between FSC PCI and national legislation. As a result, criterion 1.4 ("Conflicts between laws, regulations and the FSC Principles and Criteria shall be evaluated for the purposes of certification, on a 
case by case basis, by the certifiers and the involved or affected parties") does not apply.

The matter relating to forest employees is not recognized by the workshop participants as an issue likely to affect the ecology of the forest, and this is reflected in the analysis. The specific FSC criterion 4.3 ("The rights of workers to organize and voluntarily negotiate with their employers shall be guaranteed as outlined in Conventions 87 and 98 of the International Labor Organization (ILO)") does not address any of the threats and contributing factors in the conceptual model. Another example of non-coverage by FSC standards relates to the use of pesticides. In the case of Arkhangelsk, there is no pest management. For this reason, criterion 6.6 ("Management systems shall promote the development and adoption of environmentally friendly nonchemical methods of pest management and strive to avoid the use of chemical pesticides. World Health Organization Type $1 A$ and $1 B$ and chlorinated hydrocarbon pesticides; pesticides that are persistent, toxic or whose derivatives remain biologically active and accumulate in the food chain beyond their intended use; as well as any pesticides banned by international agreement, shall be prohibited. If chemicals are used, proper equipment and training shall be provided") and criterion 6.8. ("Use of biological control agents shall be documented, minimized, monitored and strictly controlled in accordance with national laws and internationally accepted scientific protocols. Use of genetically modified organisms shall be prohibited") do not relate to any of the threats and contributing factors recorded by the participants. Similarly, exotic species are not addressed by forest management operations in Arkhangelsk, and so, criterion 6.9. ("The use of exotic species shall be carefully controlled and actively monitored to avoid adverse ecological impacts") is not mapped into the conceptual model. Criterion 6.10 ("Forest conversion to plantations or non-forest land uses shall not occur, except in circumstances where conversion: a) entails a very limited portion of the forest management unit; and b) does not occur on high conservation value forest areas; and c) will enable clear, substantial, additional, secure, long term conservation benefits across the forest management unit") does not apply because forest in Arkhangelsk is logged exclusively for timber harvesting. The operational guidelines in the conventional forest management that influence the logging operations are not described in a way that allowed to map criterion 7.2. "The management plan shall be periodically revised to incorporate the results of monitoring or new scientific and technical information, as well as to respond to changing environmental, social and economic circumstances"). Concerning matters relating to forest economics, the criterion 8.3 ("Documentation shall be provided by the forest manager to enable monitoring and certifying organizations to trace each forest product from its origin, a process known as the "chain of custody") does not apply to the identified elements that ecologically influence the forest ecosystem.

\section{Discussion}

The findings of this study are broadly in line with the outcomes of previous research carried out on the effectiveness of FSC in that compliance with FSC standards has the potential to influence substantially most activities associated with commercial forestry [56]. Previous assessments on the effectiveness of FSC using interviews and questionnaires concluded there was a positive ecological benefit to forest biodiversity and ecosystem integrity from FSC [57]. In our conceptual model of the Arkhangelsk Region, a considerable proportion of contributing factors relating to forest management, including monitoring and evaluation but also the institutions' capacity and knowledge, were assumed to be transformed towards the better by FSC. Consequently, following the theory of change, FSC has the potential to reduce a range of anthropogenic threats such as large-scale deforestation, logging in HCVF and intact forests, large clear-cuts, excessive AAC, tree damage, and hydrological changes. However, the reduction of human-induced forest fires was assumed to be the only stress abated effectively.

The semi-quantitative evaluation of the FSC-induced influence, as estimated during the theoretical plausibility analysis, suggests that FSC could produce even more effective outcomes for biodiversity by targeting identified problems more specifically and precisely in order to generate a strong and positive influence on relevant drivers of negative environmental impacts. Quite a few FSC-induced measures seem to induce rather minor improvements. For instance, the concept of safeguarding biodiversity by adopting a 'setaside' area such as HCVF is in contrast to more contemporary thinking that advocates the ecosystem-based approach targeting functional landscape ecosystems rather than small even though representative patches. The protection of parts of commercially used forests with high conservation values and key biotopes by FSC is important for biodiversity conservation in Russia [58]. However, the size and quality of HCVF were found to be much more related to the scale and type of tenure but were also regarded as a means of demonstrating compliance with existing legislation for designated protected species, and not for maintaining or promoting ecosystem function [59]. A more in-depth analysis and evidence-based study is recommended to determine the effectiveness of current HCVF in reducing biodiversity loss and maintaining ecosystem functionality, especially in the boreal zone. More specific guidance for forest managers on the control and restoration of habitats, including riparian vegetation and wildlife corridors is strongly recommended.

A key finding is that the participatory situation analysis does not entirely match with findings gathered from the spatial analyses and field visitations. According to the conceptual model developed by the workshop participants, large-scale clear-cuts present a key problem of unsustainable forestry practices in the region. Apart from fragmenting habitats and reducing populations of organisms, this creates massive impacts on soil and hydrology, leads to largescale land cover change and is likely to change micro- and 
mesoclimate. The clear-cuts do not resemble large-scale natural disturbance such as forest fires. Fires do not lead to almost complete loss of biomass and nutrients, and do not mechanically change the soils - as industrialized timber mining does. FSC PCI would encourage small-scale, close to nature practices of harvesting that would mimic natural gap dynamics in boreal forests. This is not supported by the spatial analysis and site visits, which indicated substantial clear-cuts of 50 hectares or more, after a few years covering much larger areas of consecutively cleared forest. The conventional 'checkerboard' clear-cutting continues even after certification, and clearly progresses into IFL as shown for the example area. The loss of tree cover under certification appears to increase over time in response to a greater up-take of certification by commercial companies operating in the field. Our analysis does not suggest that FSC certification promotes large-scale clear-cutting in primary forests, but equally, there is no evidence for either a decrease or avoidance of large-scale degradation of forest cover in certified areas. Theoretically, deviations observed from expected outcomes can also be related to an incomplete implementation of FSC criteria and indicators. This would be corrected during the audits. Indeed, more than half of the so called corrective action requests (CAR) that were raised during FSC audits were related to environmental issues [60]. However, the key problem of large-scale clear-cuts in primary forests seems to be compliant with the Russian standard which gives reasons for serious concerns.

The continued practice of large-scale clear-cuts has far reaching consequences for the forest environment. In particular, it causes long-term degradation to soils and the hydrological regime, and also affects local climatic conditions. The complex ecosystem with its mosaic of mires, peats, and water systems contributes substantially to the resilience of the planet, specifically, they contribute to the global temperature balance [61] and store huge amounts of carbon [62]. However, the boreal is also a deeply vulnerable ecosystem, responding rapidly to human disturbance. Most of the fires in recent times can be attributed to human activity, and also the change in fire frequency and intensity that threatens the survival and resilience capability of the boreal zone. Regarding climate change, FSC refers to the United Nations Framework Convention on Climate Change and whilst certain criteria target climate change mitigation by restricting forest conversion (6.10), reducing erosion (6.5), and supporting forest regeneration (6.3 and 8.2), a more specific guidance on developing and adopting climate change adaptation measures is urgently needed to foster sustainable development and to ensure the provision of ecosystem services by the boreal forest of the Arkhangelsk Region in the long-term. The findings of our spatial analysis are in line with recent studies from other continents that found no or very limited effects of certification on halting tree cover loss $[18,48,63,64]$. Especially in the case of poor forest governance, forest certification alone cannot limit deforestation [65].

The disparity between theory and reality revealed in this study underpins the need for generating measurable indicators along the postulated cause-effect chains following the theory of change induced by FSC certification. By employing a definitive set of indicators as part of a complementary empirical assessment of FSC practice in the field, it should be possible to effectively assess the benefits and drawbacks of the certification scheme.

\section{Conclusions}

The theoretical plausibility analysis revealed that FSC is able to address various elements critical for the effective functioning of forest ecosystems in the Arkhangelsk Region. However, any perceived benefits on forest management were, according to the theoretical assessment, deemed to be weak and likely to result in ineffective outcomes for safeguarding biodiversity and ecosystem services in the long-term. An ecosystem-based forest management, which is specially tailored to the present situation, is highly recommended, under certification or not. The postulated success in reducing identified environmental threats and stresses through a smaller size of clear-cuts, more selective logging, and harvesting in secondary forests needs further investigation and evidence on the ground, including additional spatial analysis.

Sustainability standards that are unable to translate principles into effective action with measurable outputs will fail in meeting intended objectives of safeguarding the environment and securing human well-being. The discrepancy between the guidance provided by the $\mathrm{PCl}$ and its interpretation by certification bodies and the implementation on the ground are noted even within the FSC itself [13]. Inevitably, the setup of certification systems reflects the philosophy and expertise of its designers [66]. In the case of FSC, the three chamber system was designed to balance ecological, economic and social impacts of certification. Actually, this is not compatible with an ecosystem approach that accepts that humans and their activities are dependent components of the ecosystem, which therefore must be kept functional by all means. Recent FSC decisions on rejecting 'Motions' such as the "Landscape Approach to Protect Intact Forest Landscapes at the Landscape Level" (Motion GA2017/17, FSC 2017) at the general assembly 2017 in Vancouver, Canada, give the impression that the development of relevant ecological issues can easily be outvoted by one of the other chambers [67].

The modus operandi of FSC based on the development of national interpretations of the global principles and criteria seems to provide a solid fundament for creating an effective, regionally adequate sustainability standard. But there is no evidence that beyond the audits of certified companies or concessions, FSC systematically compiles overarching assessments on certification effectiveness for further development of the various national standards. The franchising-like approach, where a good part of the responsibility for the national standards is delegated to national experts influenced by the corresponding conceptual and 
legal frameworks, does not allow for consistency and credibility of the standard. The simple fact that, according to the Russian FSC standard (and legislation), it seems to be acceptable to exploit primeval forests by creating large-scale clear-cuts, seriously undermines the credibility of FSC.

\section{Acknowledgements}

We acknowledge the funding provided by WWF Germany. We owe special thanks to the efforts of the participants and contributors, especially Anton Studentsov, Andrey Shegolev, and Nicolay Shmatkov for their input and advice, Tatiana Yanitskaya and Mikhail Karpachevskiy for their technical support. Pierre lbisch co-conceived and supervised the study in the framework of his long-term research programme facilitated by the research professorships 'Biodiversity and natural resource management under global change' (2009-2015) as well as 'Ecosystem-based sustainable development' (since 2015) granted by Eberswalde University for Sustainable Development. We thank Monika Hoffmann for preparing and processing the spatial data.

\section{References and Notes}

[1] Forest Stewardship Council. FSC International Standard: FSC principles and criteria for forest stewardship; 1996. Available from: https://ddd.uab.cat/pub/trerecpro/2012/hdl_2072_202619/PFC AidaSalaCarmona_annex.pdf.

[2] Forest Stewardship Council. Document centre; 2017. Available from: https://ic.fsc.org/en/document-center.

[3] Forest Stewardship Council. FSC: Facts \& figures July 4, 2017. Bonn, Germany; 2017. Available from: https://ic.fsc.org/en/factsand-figures.

[4] UNEP-WCMC, Biodiversity Indicators Partnership. Area of forest under sustainable management: total FSC and PEFC forest management certification; 2017. Available from: https://www.bipindicators.net/indicators/area-of-forest-undersustainable-management-certification.

[5] MCPFE. Resolution H1: General guidelines for the sustainable management of forests in europe. Helsinki/Finland: Second Ministerial Conference on the Protection of Forests in Europe; 1993.

[6] Raum S. The ecosystem approach, ecosystem services and established forestry policy approaches in the United Kingdom. Land Use Policy. 2017;64:282-291. doi:10.1016/j.landusepol.2017.01.030.

[7] Food and Agricultural Organization of the United Nations. Sustainable forest management and the ecosystem approach: two concepts, one goal; 2003. Available from: http://www.fao.org/forestry/64170905522127db12a324c6991d0a53571fa.pdf.

[8] Convention on Biological Diversity. Ecosystem approach; 2005. Available from: https://www.cbd.int/doc/handbook/cbd-hb-all-en.pdf.

[9] Hiedanpää J, Kotilainen J, Salo M. Unfolding the organised irresponsibility: Ecosystem approach and the quest for forest biodiversity in Finland, Peru, and Russia. Forest Policy and Economics. 2011;13(3):159-165. doi:10.1016/j.forpol.2010.11.007.

[10] Ibisch PL, Vega AE, Herrmann TM. Secretariat of the Convention on Biological Diversity, Montreal (second corrected edition). Technical Series No. 54; 2010.

[11] Freudenberger L, Hobson PR, Schluck M, lbisch PL. A global map of the functionality of terrestrial ecosystems. Ecological Complexity. 2012;12:13-22. doi:10.1016/j.ecocom.2012.08.002.

[12] Burivalova Z, Hua F, Koh LP, Garcia C, Putz F. A critical comparison of conventional, certified, and community management of tropical forests for timber in terms of environmental, economic, and social variables. Conservation Letters. 2016;10(1):4-14. doi:10.1111/conl.12244.

[13] Boström M. The problematic social dimension of sustainable development: The case of the Forest Stewardship Council. The In- ternational Journal of Sustainable Development and World Ecology. 2012;19(1):3-15. doi:10.1080/13504509.2011.582891.

[14] Cerutti PO, Lescuyer G, Tacconi L, Eba'a Atyi R, Essiane E, Nasi R, et al. Social impacts of the Forest Stewardship Council certification in the Congo basin. International Forestry Review. 2017;19(S2):1-14.

[15] Kalonga S, Midtgaard F, Eid T. Does forest certification enhance forest structure? Empirical evidence from certified community-based forest management in Kilwa District, Tanzania. International Forestry Review. 2015;17(2):182-194. doi:http://www.bioone.org/doi/full/10.1505/146554815815500570.

[16] Barbosa de Lima AC, Novaes Keppe LA, Maule FE, Sparovek G, Corrêa Alves M, Maule RF. Does certification make a difference? Impact assessment study on FSC/SAN certification in Brazil. Piracicaba, Brazil: Instituto de Manejo e Certificação Florestal e Agrícola (Imaflora); 2009.

[17] Medjibe V, Putz FE, Romero C. Certified and uncertified logging concessions compared in Gabon: changes in stand structure, tree species, and biomass. Environmental Management. 2013;51:524540. doi:10.1007/s00267-012-0006-4.

[18] Miteva DA, Loucks CJ, Pattanayak SK. PLOS ONE. doi:10.1371/journal.pone.0129675.

[19] Sollmann R, Mohamed A, Niedballa J, Bender J, Ambu L, Lagan $\mathrm{P}$, et al. Quantifying mammal biodiverstiy co-benefits in certified tropical forests. Diversity and Distributions. 2017;23(3):317-328. doi:10.1111/ddi.12530.

[20] Dias FS, Bugalho MN, Rodríguez-González, P M Albuquerque A, Cerdeira JO. Effects of forest certification on the ecological condition of Mediterranean streams. Journal of Applied Ecology. 2015;52:190198. doi:10.1111/1365-2664.12358.

[21] Damette O, Delacote P. Unsustainable timber harvesting, deforestation and the role of certification. Ecological Economics. 2011;70:1211-1219. doi:10.1016/j.ecolecon.2011.01.025.

[22] Griscom B, Ellis P, Putz FE. Carbon emissions performance of commercial logging in East Kalimantan, Indonesia. Global Change Biology. 2014;20(3):923-937. doi:10.1111/gcb.12386.

[23] Cashore B, Gale F, Meidinger E, Newsom D. Forest certification in developing and transitioning countries. Part of a sustainable future? Environment: Science and Policy for Sustainable Development. 2006;48(9):6-25. doi:10.3200/ENVT.48.9.6-25.

[24] Foster BC, Wang D, Keeton WS. An exploratory, post-harvest comparison of ecological and economic characteristics of Forest Stewardship Council certified and uncertified northern hardwood stands. Journal of Sustainable Forestry. 2008;26(3):171-191. doi:10.1080/10549810701879701.

[25] Hansen MC, Stehman SV, Potapov PV. Quantification of global gross forest cover loss. PNAS. 2010;107(19):8650-8655. doi:10.1073/pnas.0912668107.

[26] Food and Agricultural Organization of the United Nations. The Russian Federation Forest Sector: Outlook Study to 2030. Rome, Italy; 2012.

[27] Syrjänen K, Kalliola R, Puolasmaa A, Mattsson J. Landscape structure and forest dynamics in subcontinental Russian European taiga. Annales zoologici Fennici. 1994;31:19-34.

[28] McDermott CL, Cashore B, Kanowski P. Central and Eastern Europe: Latvia, Poland and the Russian Federation. In: Global Environmental Forest Policies: An International Comparison. London; Washington, DC: Earthscan; 2010.

[29] Achard F, Mollicone D, Stibig HJ, Aksenov D, Laestadius L, $\mathrm{Li} \mathrm{Z}$, et al. Areas of rapid forest-cover change in boreal Eurasia. Forest Ecology and Management. 2006;237:322-334. doi:10.1016/j.foreco.2006.09.080.

[30] Aksenov D, Dobrynin D, Dubinin M, Egorov A, Isaev A, Karpachevskiy M, et al. Atlas of Russia's Intact Forest Landscapes. Moscow; 2002. Available from: http://www.intactforests.org/pdf.publications/Russian. IFL.2002.part1.pdf.

[31] Yaroshenko AY, Potapov PV, Turubanova SA. The last Intact Forest Landscapes of Northern European Russia: Mapping of intact forest landscapes in northern European Russia using high-resolution satellite images - Methods and Results. Moskow: Greenpeace Russia and Global Forest Watch; 2001.

[32] Potapov P, Hansen MC, Laestadius L, Turubanova S, Yaroshenko A, Thies C, et al. The last frontiers of wilderness: Tracking loss 
of intact forest landscapes from 2000 to 2013. Science Advances. 2017;3:1-13. doi:10.1126/sciadv.1600821.

[33] Potapov P, Yaroshenko A, Turubanova S, Dubinin M, Laestadius L, Thies C, et al. Mapping the world's intact forest landscapes by remote sensing. Ecology and Society. 2008;13(2)(51). Available from: http://www.ecologyandsociety.org/vol13/iss2/art51/Research.

[34] Simonsson P, Östlund L, Gustafsson L. Conservation values of certified-driven voluntary forest set-asides. Forest Ecology and Management. 2016;375:249-258. doi:10.1016/j.foreco.2016.05.039.

[35] Tysiachniouk M. Fostering FSC forest certification in Russia: Interplay of state and non-state actors. In: Aris S, Neumann M, Orttung R, Perović J, Pleines H, Schröder HH, et al., editors. Russian analytical digest. vol. 114. Forschungsstelle Osteuropa, Bremen and Center for Security Studies, Zürich; Research Centre for East European Studies, Publications Department, Bremen, Germany; 2012. pp. 8-11. Available from: https://www.files.ethz.ch/isn/143548/ Russian_Analytical_Digest_114.pdf.

[36] Keskitalo ECH, Sandtröm C, Tysiachniouk M, Johansson J. Local consequences of applying international norms: Differences in the application of forest certification in northern Sweden, northern Finland, and northwest Russia. Ecology and Society. 2009;14(2)(1). Available from: http://www.ecologyandsociety.org/vol14/iss2/art1/.

[37] Maletz O, Tysiachniouk M. The effect of expertise on the quality of forest standards implementation: The case of FSC forest certification in Russia. Forest Policy and Economics. 2009;11(5-6):422-428. doi:10.1016/j.forpol.2009.03.002.

[38] Matilainen AM. Forest companies, corporate social responsibility, and company stakeholders in the Russian forest sector. Forest Policy and Economics. 2013;31:44-49. doi:10.1016/j.forpol.2011.12.006.

[39] Aakala T, Kuuluvainen T, Wallenius T, Kauhanen H. Tree mortality episodes in the intact Picea abies-dominated taiga in the Arkhangelsk region of northern European Russia. Journal of Vegetation Science. 2011;22:322-333. doi:10.1111/j.1654-1103.2010.01253.x.

[40] Dobrynin D, Kirillov A, Maksutova N, Markovsky A, Noskova M, Petrov V. 5.3. HCV areas requiring urgent protective measures in 2011-2013. In: Kobyakov K, Jakovlev J, editors. Atlas of high conservation value areas, and analysis of gaps and representativeness of the protected area network in northwest Russia: Arkhangelsk, Vologda, Leningrad, and Murmansk Regions, Republic of Karelia, and City of St. Petersburg. Helsinki: Finnish Environment Institute; 2013. pp. 211-230.

[41] Surinov A, Zbarskaya I. The demographic yearbook of Russia: Statistical handbook. Moscow: Federal State Statistics Service (Rosstat); 2010.

[42] Björklund J. Exploiting the last phase of the north European timber frontier for the international market 1890-1914: an economichistorical approach. In: Forest History: international studies on socioeconomic and forest ecosystem change. Agnoletti M, Anderson S, editors; 1998

[43] Glazunov M. Business in post-Cummunist Russia: privatisation and the limits of transformation. Glazunov M, editor. London and New York: Routledge; 2013

[44] Hernesniemi H. Item 10: presentation of the "The northwest Russian forest cluster project". In: FAO Advisory Committee on Paper and Wood Products. Rome, Italy; 2002. Available from: http: //www.fao.org/docrep/005/Y3909E/Y3909e08.htm\#P1500_154640.

[45] Schick A, Hobson PR, Ibisch PL. Conservation and sustainable development in a VUCA world: the need for a systemic and ecosystembased approach. Ecosystem Health and Sustainability. 2016;3(4):112. doi:10.1002/ehs2.1267.

[46] Ibisch PL, Hobson P. MARISCO: adaptive MAnagement of vulnerability and RISk at COnservation sites. Ibisch PL, Hobson PR, editors. Eberswalde: Centre for Econics and Ecosystem Management; 2014.

[47] Romero C, Putz FE, Guariguata MR, Sills EO, Cerutti PO, Lescuyer G. An overview of current knowledge about the impacts of forest management certification: A proposed framework for its evaluation. Occasional Paper 91. CIFOR, Bogor, Indonesia; 2013.

[48] Romero C, Sills EO, Guariguata MR, Cerutti PO, Lescuyer G, Putz FE. Evaluation of the impacts of Forest Stewardship Council (FSC) certification of natural forest management in the tropics: a rigorous approach to assessment of a complex conservation intervention. International Forestry Review. 2017;19(S2):1-14.

[49] Blumröder JS, Hoffmann MT, Winter S, Krüger JA, Gräbener UF, Hobson PR, et al. Ecosystem-based assessment of sustainability standards and their effectiveness: Methodological framework. Berlin: WWF Germany; 2017.

[50] Hansen MC, Potapov PV, Moore R, Hancher M, Turubanova Sa, Tyukavina $A$, et al. High-resolution global maps of 21st-century forest cover change. Science. 2013;342:850-853. doi:10.1126/science.1244693.

[51] Transparent World.; $2016 . \quad$ Available from: https://ru.fsc.org/preview.fsc.a-1780.jpg.

[52] Forest Stewardship Council, F000100 F. Public Certificate Search; 2016. Available from: https://info.fsc.org/certificate.php.

[53] Desktop EA. Redlands, CA: Environmental Systems Research Institute. Release; 2011.

[54] Meadows D. Leverage Points: Places to Intervene in a System. Hartland: The Sustainability Institute; 1999. Available from: http: //donellameadows.org/wp-content/userfiles/Leverage_Points.pdf.

[55] DIVA-GIS. Free Spatial Data;. Available from: http://www.divagis.org/Data.

[56] Moore SE, Cubbage F, Eicheldinger C. Impacts of Forest Stewardship Council (FSC) and Sustainable Forestry Initiative (SFI) forest certification in North America. Journal of Forestry. 2012;110(2):79-88. doi:http://dx.doi.org/10.5849/jof.10-050.

[57] Gafo Gomez-Zamalloa M, Caparros A, San-Miguel Ayanz A. 15 years of forest certification in the European Union. Are we doing things right? Forest Systems. 2011;20(1):81-94. Available from: www.inia.es/forestsystems.

[58] Baisheva EZ, Mirkin BM, Naumova LG, Martynenko VB, Shirokikh PS. Biological diversity of ecosystems: Approaches to research and conservation. Biology Bulletin Reviews. 2015;5(2):138-147. doi:10.1134/S2079086415020036.

[59] Ioras F, Abrudan IV, Dautbasic M, Avdibegovic M, Gurean D, Ratnasingam J. Conservation gains through HCVF assessments in Bosnia-Herzegovina and Romania. Biodiversity and Conservation. 2009;18:3395-3406. doi:10.1007/s10531-009-9649-8.

[60] Hirschberger P. The effects of FSC-certification in Russia: An analysis of Corrective Action Requests. WWF European Forest Programme, WWF Austria; 2005. Available from: https://www.google.de/url?sa=t\&rct=j\&q=\&esrc=s\&source=web\& $c d=2 \& v e d=0$ ahUKEwiH5t3ssNfZAhVHr6QKHernCqkQFggwMAE\& url=http\%3A\%2F\%2Fwww.panda.org\%2Fdownloads\%2Fforests\% 2Ffscanalysisrussia.pdf\&usg=AOvVaw2kOw1TdSBXOklre_9qLCj.

[61] Snyder PK, Delire C, Foley JA. Evaluating the influence of different vegetation biomes on the global climate. Climate Dynamics. 2004;23:279-302. doi:10.1007/s00382-004-0430-0.

[62] Bonan GB. Forests and climate change: forcings, feedbacks, and the climate benefits of forests. Science. 2008;320:1444-9. doi:10.1126/science.1155121.

[63] Blackman A, Goff L, Planter MR. Does eco-certification stem tropical deforestation? Forest Stewardship Council certification in Mexico. Washington, DC, USA: Resources for the Future; 2015.

[64] Panlasigui S, Rico-Straffon J, Swenson J, Loucks CJ, Pfaff A. Early days in the certification of logging concessions: Estimating FSC's deforestation impact in Peru and Cameroon; 2015.

[65] Ebeling J, Yasué M. The effectiveness of market-based conservation in the tropics: Forest certification in Ecuador and Bolivia. Journal of Environmental Management. 2009;90(2):1145-1153. doi:10.1016/j.jenvman.2008.05.003.

[66] Rametsteiner E, Simula M. Forest certification—an instrument to promote sustainable forest management? Journal of Environmental Management. 2003;67:87-98. doi:10.1016/S0301-4797(02)00191-3.

[67] Forest Stewardship Council. All motions not passed - FSC General Assembly 2017; 2017. Available from: https://ga2017.fsc.org/all-notpassed-motions/. 


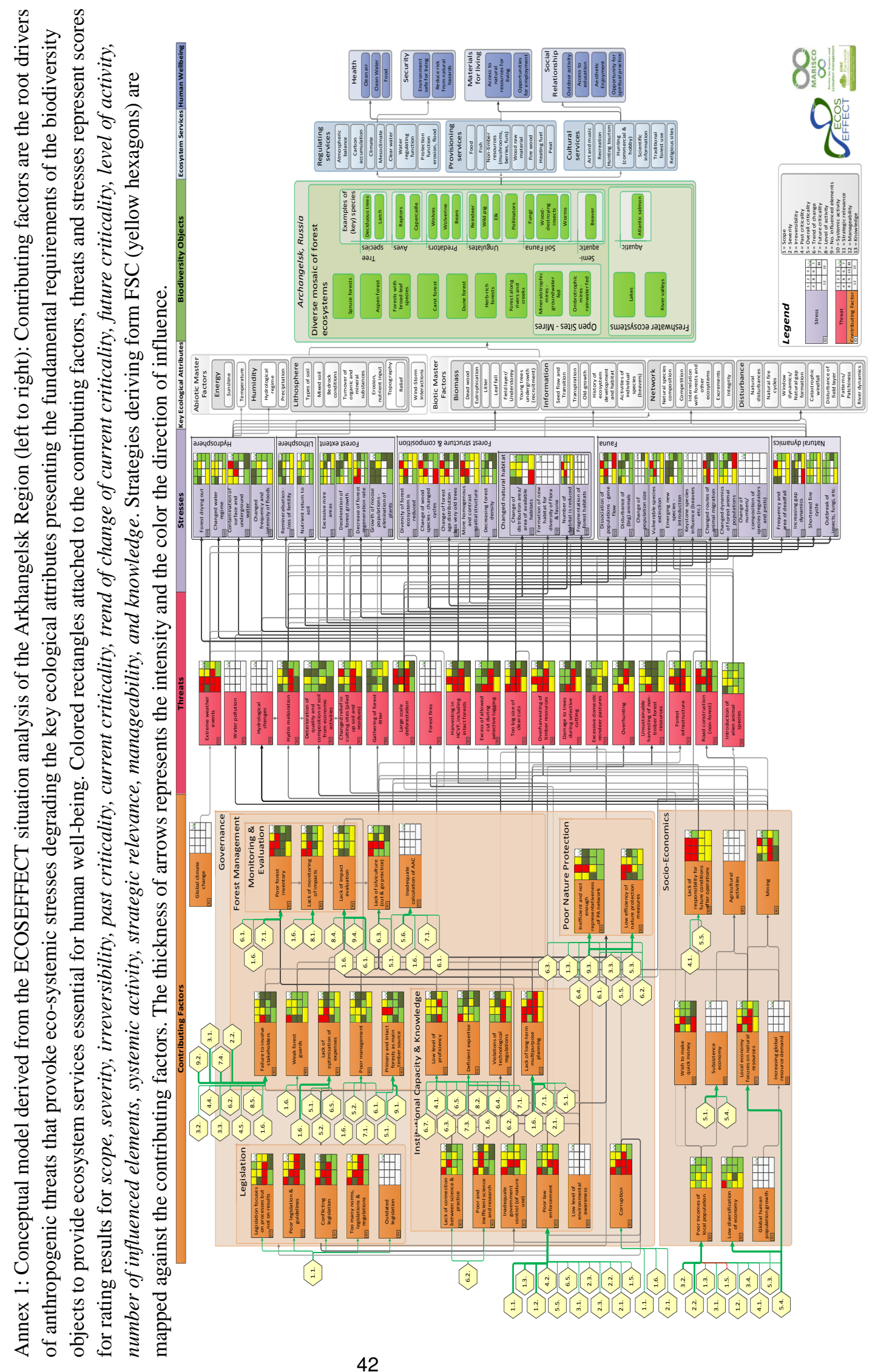


Annex 2: Contributing factors that were identified and rated during the study (ordered according to the descending strategic relevance).

\begin{tabular}{|c|c|c|c|c|c|c|c|c|c|c|c|c|}
\hline$\#$ & Contributing factor & 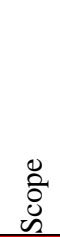 & 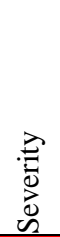 & 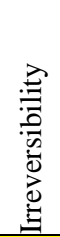 & 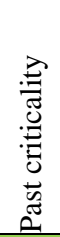 & 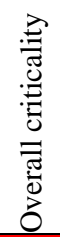 & 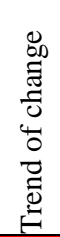 & 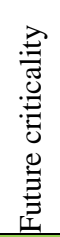 & 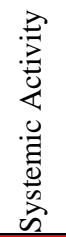 & 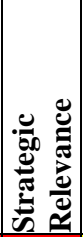 & 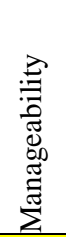 & $\begin{array}{l}0 \\
0 \\
\frac{0}{0} \\
0 \\
0 \\
0 \\
0\end{array}$ \\
\hline 1 & $\begin{array}{l}\text { Lack of long-term multipurpose } \\
\text { planning }\end{array}$ & 4 & 4 & 3 & 2 & 4 & 4 & 2 & 4 & 4 & 3 & 3 \\
\hline 2 & $\begin{array}{l}\text { Too many norms, legislations \& } \\
\text { regulations }\end{array}$ & 4 & 3 & 3 & 1 & 4 & 3 & 3 & 4 & 4 & 2 & 2 \\
\hline 3 & Poor legislation \& guidelines & 4 & 3 & 3 & 1 & 4 & 3 & 3 & 4 & 4 & 2 & 1 \\
\hline 4 & $\begin{array}{l}\text { Inadequate government control (of } \\
\text { nature use) }\end{array}$ & 4 & 3 & 3 & 1 & 4 & 3 & 2 & 3 & 3 & 3 & 2 \\
\hline 5 & Corruption & 4 & 3 & 3 & 1 & 4 & 3 & 2 & 4 & 3 & 4 & 2 \\
\hline 6 & $\begin{array}{l}\text { Poor and inefficient science and } \\
\text { research }\end{array}$ & 4 & 3 & 3 & 3 & 4 & 4 & 1 & 2 & 3 & 2 & 1 \\
\hline 7 & $\begin{array}{l}\text { Local economy focuses on natural } \\
\text { resources }\end{array}$ & 4 & 3 & 3 & 2 & 4 & 2 & 2 & 4 & 3 & 3 & 2 \\
\hline 8 & $\begin{array}{l}\text { Lack of responsibility for future } \\
\text { conditions after operations }\end{array}$ & 4 & 4 & 4 & 4 & 4 & 4 & 2 & 3 & 3 & 3 & 3 \\
\hline 9 & Poor law enforcement & 4 & 2 & 2 & 1 & 3 & 3 & 2 & 3 & 3 & 4 & 2 \\
\hline 10 & $\begin{array}{l}\text { Legislation focuses on processes but } \\
\text { not on results }\end{array}$ & 3 & 3 & 2 & 1 & 3 & 3 & 3 & 4 & 3 & 2 & 1 \\
\hline 11 & Low level of proficiency & 2 & 3 & 3 & 1 & 3 & 3 & 1 & 4 & 3 & 2 & 2 \\
\hline 12 & Mining & 1 & 3 & 4 & 2 & 3 & 2 & 2 & 4 & 3 & 1 & 2 \\
\hline 13 & Poor forest inventory & 4 & 4 & 3 & 1 & 4 & 4 & 1 & 1 & 2 & 3 & 1 \\
\hline 14 & Lack of monitoring of impacts & 4 & 3 & 3 & 4 & 4 & 1 & 1 & 2 & 2 & 3 & 3 \\
\hline 15 & Lack of optimisation of expenses & 4 & 3 & 3 & 4 & 4 & 1 & 1 & 2 & 2 & 2 & 3 \\
\hline 16 & $\begin{array}{l}\text { Low efficiency of nature protection } \\
\text { measures }\end{array}$ & 4 & 4 & 3 & 1 & 4 & 3 & 1 & 2 & 2 & 2 & 3 \\
\hline 17 & $\begin{array}{l}\text { Inefficient and not enough } \\
\text { representativeness of PA network }\end{array}$ & 3 & 4 & 3 & 3 & 4 & 1 & 1 & 2 & 2 & 2 & 2 \\
\hline 18 & Conflicting legislation & 4 & 3 & 3 & 1 & 4 & 1 & 1 & 4 & 2 & 2 & 2 \\
\hline 19 & $\begin{array}{l}\text { Lack of connection between science \& } \\
\text { practice }\end{array}$ & 4 & 3 & 3 & 2 & 4 & 2 & 1 & 3 & 2 & 2 & 2 \\
\hline 20 & Wish to make quick money & 4 & 3 & 3 & 2 & 4 & 2 & 2 & 2 & 2 & 4 & 1 \\
\hline 21 & Lack of silviculture (cut \& go practice) & 4 & 4 & 3 & 2 & 4 & 1 & 2 & 3 & 2 & 2 & 1 \\
\hline 22 & $\begin{array}{l}\text { Primary and intact forests as main } \\
\text { timber source }\end{array}$ & 3 & 4 & 3 & 2 & 4 & 2 & 1 & 2 & 2 & 2 & 1 \\
\hline 23 & Lack of impact evaluation & 3 & 3 & 3 & 1 & 3 & 3 & 1 & 2 & 2 & 3 & 3 \\
\hline 24 & Weak forest guards & 4 & 2 & 3 & 1 & 3 & 3 & 2 & 2 & 2 & 3 & 2 \\
\hline 25 & Violations of technological regulations & 2 & 3 & 3 & 2 & 3 & 1 & 1 & 4 & 2 & 2 & 3 \\
\hline 26 & Deficient expertise & 4 & 2 & 2 & 3 & 3 & 1 & 1 & 3 & 2 & 2 & 1 \\
\hline 27 & Low diversification of economy & 4 & 2 & 2 & 2 & 3 & 2 & 2 & 2 & 2 & 3 & 2 \\
\hline 28 & Poor incomes of local population & 3 & 2 & 2 & 2 & 3 & 2 & 2 & 3 & 2 & 3 & 2 \\
\hline 29 & Failure to involve stakeholders & 3 & 3 & 3 & 4 & 3 & 1 & $\overline{1}$ & 2 & 1 & 2 & $\overline{1}$ \\
\hline 30 & Poor management & 2 & 3 & 3 & 3 & 3 & 1 & 1 & 2 & 1 & 2 & 3 \\
\hline 31 & Global climate change & NA & NA & NA & NA & NA & NA & NA & NA & NA & NA & NA \\
\hline 32 & Global human population growth & NA & NA & NA & NA & NA & NA & NA & NA & NA & NA & NA \\
\hline 33 & Inadequate calculation of AAC & NA & NA & NA & NA & NA & NA & NA & NA & NA & NA & NA \\
\hline 34 & Outdated legislation & NA & NA & NA & NA & NA & NA & NA & NA & NA & NA & NA \\
\hline 35 & Agricultural activities & NA & NA & NA & NA & NA & NA & NA & NA & NA & NA & NA \\
\hline 36 & Subsistence economy & NA & NA & NA & NA & NA & NA & NA & NA & NA & NA & NA \\
\hline 37 & Increasing global resource demand & NA & NA & NA & NA & NA & NA & NA & NA & NA & NA & NA \\
\hline 38 & Low level of environmental awareness & NA & NA & NA & NA & NA & NA & NA & NA & NA & NA & NA \\
\hline
\end{tabular}


Annex 3: Threats that were identified and rated during the study (ordered according to the descending strategic relevance)

\begin{tabular}{|c|c|c|c|c|c|c|c|c|c|c|c|c|}
\hline \# & Threat & 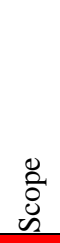 & 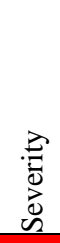 & 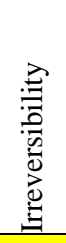 & 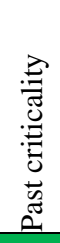 & 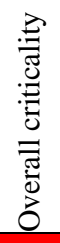 & 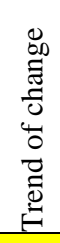 & 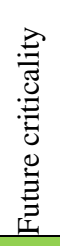 & 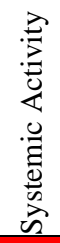 & 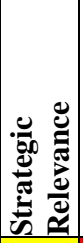 & 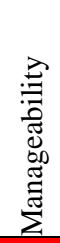 & $\begin{array}{l}0 \\
\frac{0}{0} \\
\frac{0}{3} \\
0 \\
0 \\
0\end{array}$ \\
\hline 1 & Extreme weather events & 4 & 4 & 3 & 1 & 4 & 3 & 2 & 4 & 3 & 4 & 2 \\
\hline 2 & Forest infrastructure & 3 & 4 & 3 & 4 & 4 & 1 & 2 & 4 & 3 & 3 & 2 \\
\hline 3 & Overharvesting of timber resources & 3 & 4 & 3 & 4 & 4 & 2 & 1 & 4 & 3 & 3 & 2 \\
\hline 4 & Road construction (non-forest) & 1 & 4 & 4 & 2 & 4 & 2 & 2 & 4 & 3 & 2 & 2 \\
\hline 5 & Large scale deforestation & 1 & 4 & 4 & 3 & 4 & 1 & 2 & 4 & 3 & 2 & 1 \\
\hline 6 & $\begin{array}{l}\text { Changed relief in cutting sites (piled up } \\
\text { soil and residues) }\end{array}$ & 1 & 3 & 4 & 2 & 3 & 2 & 2 & 4 & 3 & 1 & 3 \\
\hline 7 & $\begin{array}{l}\text { Harvesting in HCVF, including intact } \\
\text { forests }\end{array}$ & 3 & 4 & 3 & 4 & 4 & 1 & 1 & 4 & 2 & 3 & 1 \\
\hline 8 & Too big size of clear cuts & 4 & 3 & 3 & 4 & 4 & 1 & 1 & 4 & 2 & 3 & 1 \\
\hline 9 & Hydro melioration & 1 & 3 & 3 & 2 & 3 & 1 & 1 & 4 & 2 & 1 & 2 \\
\hline 10 & Overhunting & 3 & 2 & 2 & 4 & 3 & 1 & 1 & 4 & 2 & 3 & 1 \\
\hline 11 & Introduction of alien animal species & 1 & 3 & 3 & 2 & 3 & 2 & 2 & 3 & 2 & 2 & 2 \\
\hline 12 & $\begin{array}{l}\text { Excess of allowed cut during selective } \\
\text { logging }\end{array}$ & 1 & 2 & 2 & 4 & 2 & 1 & 2 & 4 & 2 & 3 & 1 \\
\hline 13 & $\begin{array}{l}\text { Damage to trees during selective } \\
\text { cutting }\end{array}$ & 1 & 2 & 2 & 4 & 2 & 2 & 1 & 4 & 2 & 3 & 1 \\
\hline 14 & Gathering of forest litter & 1 & 1 & 1 & 2 & 1 & 2 & 2 & 3 & 2 & 1 & 3 \\
\hline 15 & Excessive domestic reindeer pastures & 1 & 1 & 1 & 2 & 1 & 2 & 2 & 3 & 2 & 1 & 3 \\
\hline 16 & $\begin{array}{l}\text { Unsustainable harvesting of non-timber } \\
\text { forest resources }\end{array}$ & 2 & 3 & 3 & 4 & 3 & 1 & 1 & 1 & 1 & 3 & 2 \\
\hline 17 & $\begin{array}{l}\text { Deterioration of quality and } \\
\text { composition of soil from economic } \\
\text { activities }\end{array}$ & 2 & 3 & 1 & 2 & 2 & 1 & 2 & 2 & 1 & 1 & 2 \\
\hline 18 & Hydrological changes & NA & NA & NA & NA & NA & NA & NA & NA & NA & NA & $\mathrm{NA}$ \\
\hline 19 & Water pollution & NA & NA & NA & NA & NA & NA & NA & NA & NA & NA & NA \\
\hline 20 & Forest fires & NA & NA & NA & NA & NA & NA & NA & NA & NA & NA & NA \\
\hline
\end{tabular}


Annex 4: Stresses that were identified and rated during the study (ordered according to the descending strategic relevance).

\begin{tabular}{|c|c|c|c|c|c|c|c|c|c|c|c|}
\hline \# & Stress & 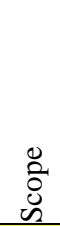 & 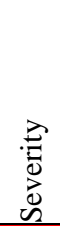 & 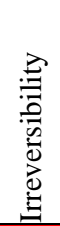 & 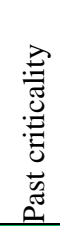 & 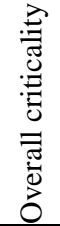 & 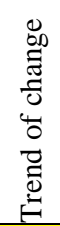 & 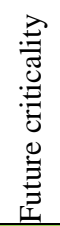 & 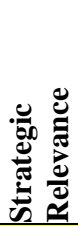 & 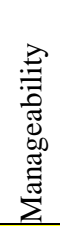 & 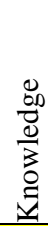 \\
\hline 1 & $\begin{array}{l}\text { More homogenous and contrast spatial } \\
\text { structure }\end{array}$ & 3 & 4 & 4 & 1 & 4 & 3 & 2 & 3 & 3 & 3 \\
\hline 2 & $\begin{array}{l}\text { Diversity of forest ecosystem is } \\
\text { reduced }\end{array}$ & 3 & 3 & 4 & 1 & 4 & 3 & 2 & 3 & 2 & 3 \\
\hline 3 & Number of habitat is reduced & 2 & 3 & 4 & 1 & 4 & 3 & 2 & 3 & 3 & 3 \\
\hline 4 & $\begin{array}{l}\text { Contamination of surface and } \\
\text { underground water }\end{array}$ & 3 & 3 & 4 & 3 & 4 & 1 & 2 & 2 & 2 & 1 \\
\hline 5 & Decrease of forest regeneration rate & 4 & 3 & 3 & 4 & 4 & 2 & 1 & 2 & 2 & 2 \\
\hline 6 & Dissociation of populations - gene flow & 3 & 3 & 4 & 1 & 4 & 2 & 1 & 2 & 3 & 4 \\
\hline 7 & $\begin{array}{l}\text { Change of forest age distribution - less } \\
\text { very old trees }\end{array}$ & 3 & 3 & 4 & 3 & 4 & 2 & 1 & 2 & 2 & 1 \\
\hline 8 & Vulnerable species extinction & 3 & 2 & 4 & 2 & 4 & 2 & 2 & 2 & 3 & 3 \\
\hline 9 & $\begin{array}{l}\text { Change of wood species - changed } \\
\text { cycles }\end{array}$ & 3 & 3 & 4 & 3 & 4 & 2 & 1 & 2 & 4 & 2 \\
\hline 10 & Changed water regime & 2 & 3 & 3 & 1 & 3 & 3 & 2 & 2 & 3 & 2 \\
\hline 11 & Frequency and area of deadfall & 1 & 3 & 4 & 1 & 3 & 3 & 2 & 2 & 3 & 3 \\
\hline 12 & $\begin{array}{l}\text { Change of distribution area/ area of } \\
\text { available habitats }\end{array}$ & 1 & 2 & 3 & 1 & 3 & 3 & 2 & 2 & 4 & 3 \\
\hline 13 & Nutrient return to soil & 1 & 2 & 3 & 2 & 3 & 2 & 3 & 2 & 2 & 2 \\
\hline 14 & Shortened fire cycle & 2 & 3 & 2 & 2 & 3 & 2 & 2 & 2 & 3 & 3 \\
\hline 15 & Demineralization - loss of fertility & 2 & 1 & 1 & 1 & 2 & 3 & 2 & 2 & 3 & 3 \\
\hline 16 & Forest drying out & 2 & 2 & 2 & 1 & 2 & 3 & 2 & 2 & 3 & 2 \\
\hline 17 & $\begin{array}{l}\text { Changed frequency and intensity of } \\
\text { floods }\end{array}$ & 1 & 1 & 2 & 2 & 2 & 3 & 2 & 2 & 3 & 2 \\
\hline 18 & Changed routes of animal migration & 2 & 3 & 4 & 4 & 4 & 1 & 1 & 1 & 3 & 2 \\
\hline 19 & Excessive mire areas & 2 & 2 & 3 & 3 & 3 & 1 & 2 & 1 & 2 & 3 \\
\hline 20 & $\begin{array}{l}\text { Changed dynamics of forest animal } \\
\text { populations }\end{array}$ & 3 & 2 & 2 & 3 & 3 & 1 & 2 & 1 & 3 & 4 \\
\hline 21 & Deceleration of forest growth & 2 & 1 & 1 & 3 & 2 & 1 & 2 & 1 & 2 & 3 \\
\hline 22 & Decreasing forest density & 2 & 2 & 2 & 3 & 2 & 1 & 2 & 1 & 2 & 1 \\
\hline 23 & Outbreak of insects, fungi, etc. & 2 & 2 & 2 & 2 & 2 & 2 & 2 & 1 & 3 & 2 \\
\hline 24 & Disturbance of (big) animals & 1 & 2 & 1 & 3 & 2 & 1 & 2 & 1 & 2 & 2 \\
\hline 25 & Increasing gap dynamics & 1 & 1 & 1 & 1 & 1 & 3 & 2 & 1 & 4 & 3 \\
\hline 26 & Emerging new species - introduction & 1 & 1 & 1 & 3 & 1 & 1 & 2 & 1 & 2 & 2 \\
\hline 27 & $\begin{array}{l}\text { Growth of moose populations - } \\
\text { elimination of plants }\end{array}$ & 1 & 1 & 1 & 1 & 1 & 3 & 2 & 1 & 2 & 1 \\
\hline 28 & Change of population size & NA & NA & NA & NA & NA & NA & NA & NA & NA & NA \\
\hline 29 & $\begin{array}{l}\text { Formation of new habitat for diversity } \\
\text { of flora \& fauna }\end{array}$ & NA & NA & NA & NA & NA & NA & NA & NA & NA & NA \\
\hline 30 & $\begin{array}{l}\text { Change of numbers/ composition of } \\
\text { species (regulators and pests) }\end{array}$ & NA & NA & NA & NA & NA & NA & NA & NA & NA & NA \\
\hline 31 & $\begin{array}{l}\text { Keystone species influence (beavers } \\
\text { etc.) }\end{array}$ & NA & NA & NA & NA & NA & NA & NA & NA & NA & NA \\
\hline 32 & Fragmentation of forest habitats & NA & NA & NA & NA & NA & NA & NA & NA & NA & NA \\
\hline
\end{tabular}


Annex 5: Contributing factors that were influenced by FSC Criteria and changed into a result.

\begin{tabular}{|c|c|c|c|c|}
\hline $\begin{array}{l}\text { Contributing factor addressed by } \\
\text { FSC }\end{array}$ & 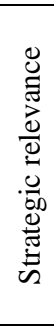 & 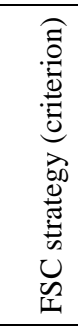 & 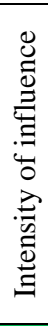 & Result \\
\hline & & 1.6. & 4 & 1.6.3. Long-term commitment to FSC is available \\
\hline & & 7.1. & 4 & $\begin{array}{l}\text { MP provides rationale for forest use, regeneration, } \\
\text { protection and fire management system. Rationale for } \\
\text { harvesting practice is available }\end{array}$ \\
\hline & & 2.1. & 3 & $\begin{array}{l}\text { Long-term lease agreements are available (minimum } 5 \\
\text { years) }\end{array}$ \\
\hline $\begin{array}{l}\text { Lack of long-term multipurpose } \\
\text { planning }\end{array}$ & 4 & 5.1. & 3 & $\begin{array}{l}\text { Economically sustainable forest management taking into } \\
\text { account environmental, social and operational expenses }\end{array}$ \\
\hline $\begin{array}{l}\text { Too many norms, legislations \& } \\
\text { regulations }\end{array}$ & 4 & 1.1. & 3 & $\begin{array}{l}\text { Negative influence of ineffective norms of current } \\
\text { legislation for forests and forestry is reduced by FSC } \\
\text { requirements }\end{array}$ \\
\hline Poor legislation \& guidelines & 4 & 1.1. & 3 & $\begin{array}{l}\text { Negative influence of ineffective norms of current } \\
\text { legislation for forests and forestry is reduced by FSC } \\
\text { requirements }\end{array}$ \\
\hline \multirow[b]{11}{*}{ Poor law enforcement } & & 1.1. & 4 & Better law enforcement. No illegal activities \\
\hline & & 1.2. & 4 & $\begin{array}{l}\text { All payments of the forest company are made in } \\
\text { compliance with (national) laws }\end{array}$ \\
\hline & & 2.1. & 4 & FM is in compliance with land-use rights \\
\hline & & 4.2. & 4 & $\begin{array}{l}\text { Health and safety issues are in compliance with laws } \\
\text { and/or regulations }\end{array}$ \\
\hline & & 1.3 . & 3 & $\begin{array}{l}\text { Forest management is compliance with international } \\
\text { treaties and conventions ratified by the Russian Federation }\end{array}$ \\
\hline & & 1.5 . & 3 & $\begin{array}{l}\text { Illegal and unauthorized activities (illegal harvesting, } \\
\text { seizure of land, etc.) are revealed, documented and } \\
\text { prevented }\end{array}$ \\
\hline & & 2.2 . & 3 & Local communities can use forest resources unrestricted \\
\hline & & 2.3 . & 3 & $\begin{array}{l}\text { Disputes and grievances over ownership and forest } \\
\text { resource use are resolved }\end{array}$ \\
\hline & & 3.1. & 3 & Rights and resources of indigenous peoples are respected \\
\hline & & 5.5 . & 3 & $\begin{array}{l}\text { Laws and regulations on water protection zones are } \\
\text { observed or exceeded }\end{array}$ \\
\hline & & 6.5 . & 3 & $\begin{array}{l}\text { Administrative regulations and guidelines on road and } \\
\text { bridge construction are observed }\end{array}$ \\
\hline \multirow[b]{3}{*}{ Corruption } & \multirow[b]{3}{*}{3} & 1.1. & 3 & Corruption is reduced \\
\hline & & 1.6. & 3 & Corruption is reduced \\
\hline & & 2.1. & 3 & Corruption is reduced \\
\hline $\begin{array}{l}\text { Legislation focuses on processes } \\
\text { but not on results }\end{array}$ & 3 & 1.1. & 3 & $\begin{array}{l}\text { Replacement of poor legislation. Better enforcement of } \\
\text { legislation }\end{array}$ \\
\hline $\begin{array}{l}\text { Poor and inefficient science and } \\
\text { research }\end{array}$ & 3 & 6.2 . & 3 & $\begin{array}{l}\text { Measures on protection and monitoring of HCVF, key } \\
\text { habitats and rare, threatened and endangered species are } \\
\text { developed in consultation with specialist and stakeholders }\end{array}$ \\
\hline \multirow[b]{4}{*}{ Low level of proficiency } & \multirow[b]{4}{*}{3} & 1.6. & 3 & FSC requirements are known to staff \\
\hline & & 4.1. & 3 & $\begin{array}{l}\text { Extension of professional knowledge and skills through } \\
\text { professional training from local people }\end{array}$ \\
\hline & & 6.2 . & 3 & $\begin{array}{l}\text { Staff is aware of materials about species and key habitats. } \\
\text { Stakeholders and agencies are supported in controlling } \\
\text { hunting and fishing }\end{array}$ \\
\hline & & 6.3. & 3 & Data on ecological changes is recorded regularly \\
\hline
\end{tabular}




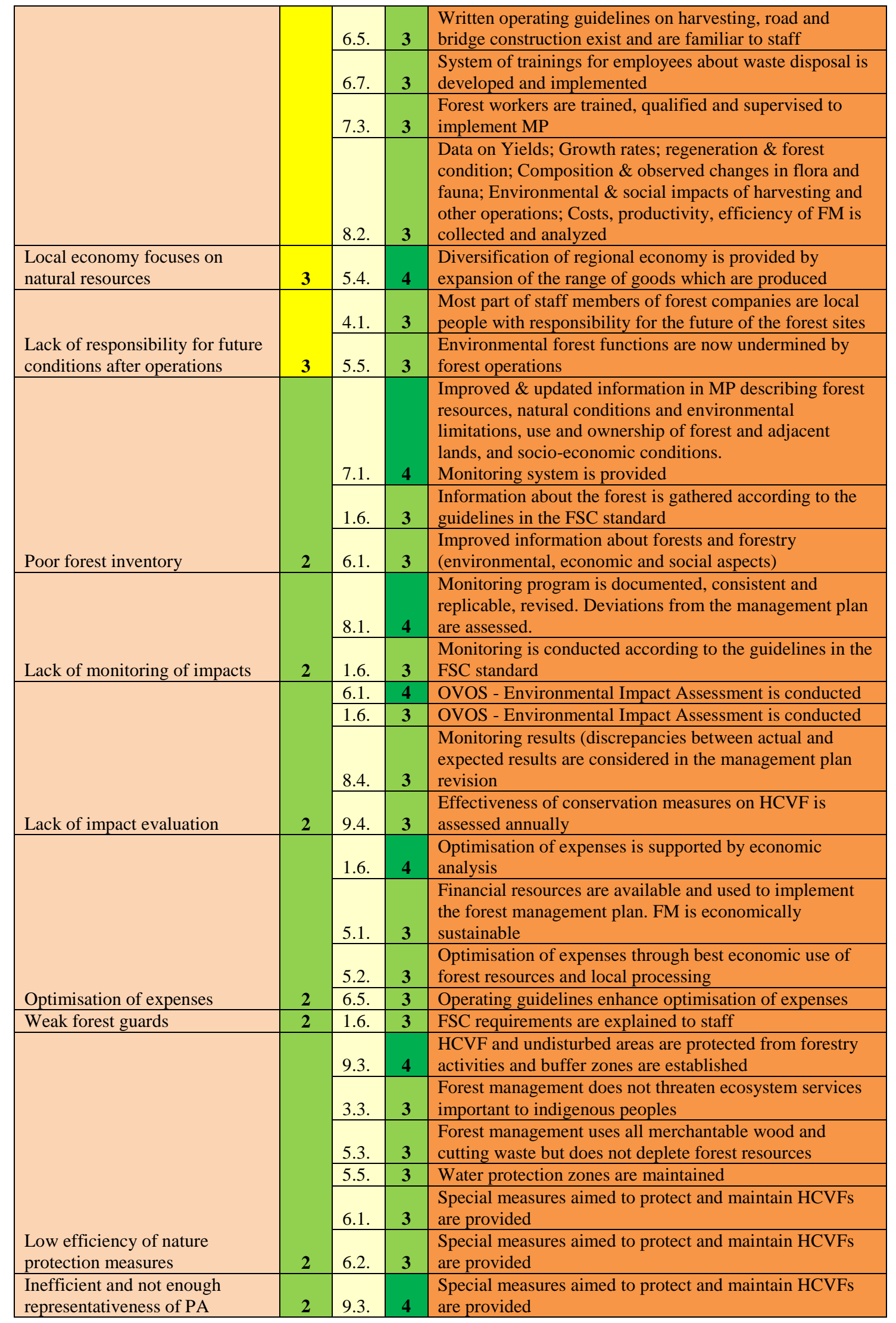




\begin{tabular}{|c|c|c|c|c|}
\hline \multirow[t]{5}{*}{ network } & & 1.3 . & 3 & $\begin{array}{l}\text { Planning and implementation of forest management takes } \\
\text { into account international treaties and conventions on } \\
\text { biodiversity conservation (and protected areas) }\end{array}$ \\
\hline & & 6.1 . & 3 & $\begin{array}{l}\text { Special measures aimed to protect and maintain HCVFs } \\
\text { are provided }\end{array}$ \\
\hline & & 6.2 . & 3 & $\begin{array}{l}\text { Special measures aimed to protect and maintain HCVFs } \\
\text { are provided }\end{array}$ \\
\hline & & 6.3 . & 3 & $\begin{array}{l}\text { Restoration of areas degraded by forest management } \\
\text { activities }\end{array}$ \\
\hline & & 6.4 . & 3 & $\begin{array}{l}\text { A network of representative examples of existing } \\
\text { ecosystems is established and management restrictions are } \\
\text { observed }\end{array}$ \\
\hline Conflicting legislation & 2 & 1.1. & 3 & Clear forest legislation is in place \\
\hline $\begin{array}{l}\text { Lack of connection between } \\
\text { science \& practice }\end{array}$ & 2 & 6.2 . & 3 & $\begin{array}{l}\text { Measures on protection and monitoring of rare, threatened } \\
\text { and endangered species are developed by researchers and } \\
\text { implemented }\end{array}$ \\
\hline \multirow[b]{4}{*}{ Deficient expertise } & \multirow[b]{4}{*}{2} & 1.6. & 3 & FSC requirements are explained to staff \\
\hline & & 6.2 . & 3 & Best available information is gathered \\
\hline & & 6.4. & 3 & $\begin{array}{l}\text { Information on existing samples of representative } \\
\text { ecosystems is gathered }\end{array}$ \\
\hline & & 7.1. & 3 & $\begin{array}{l}\text { MP provides plans for monitoring system, environmental } \\
\text { safeguards, identification and protection of HCVF, } \\
\text { representative samples, threated and endangered species } \\
\text { and habitats; Maps }\end{array}$ \\
\hline \multirow[b]{2}{*}{ Low diversification of economy } & \multirow[b]{2}{*}{2} & 5.4. & 4 & $\begin{array}{l}\text { Organization expands the range of goods including own } \\
\text { processing }\end{array}$ \\
\hline & & 5.3 . & 3 & $\begin{array}{l}\text { Organization expands the range of goods including own } \\
\text { processing }\end{array}$ \\
\hline \multirow[b]{9}{*}{$\begin{array}{l}\text { Poor incomes of local } \\
\text { population }\end{array}$} & \multirow[b]{9}{*}{2} & 2.2 . & 4 & $\begin{array}{l}\text { Local communities can have incomes through unrestricted } \\
\text { forest resources use }\end{array}$ \\
\hline & & 3.2 . & 4 & $\begin{array}{l}\text { Natural resources of indigenous peoples are respected and } \\
\text { compensated if threatened or depleted }\end{array}$ \\
\hline & & 1.2. & 3 & $\begin{array}{l}\text { Enforcement of legislation provides taxes and support } \\
\text { local budgets }\end{array}$ \\
\hline & & 1.3. & 3 & $\begin{array}{l}\text { Possibility to increase the salary due to negotiations } \\
\text { between employers and employees by implementing } \\
\text { international norms }\end{array}$ \\
\hline & & 3.1. & 3 & $\begin{array}{l}\text { Indigenous peoples can have incomes through unrestricted } \\
\text { forest resources use }\end{array}$ \\
\hline & & 3.4. & 3 & $\begin{array}{l}\text { Indigenous people receive compensations for losses and } \\
\text { the application of their knowledge in FA }\end{array}$ \\
\hline & & 4.1. & 3 & $\begin{array}{l}\text { Most part of staff members of the forest organization are } \\
\text { local people }\end{array}$ \\
\hline & & 5.4 . & 3 & $\begin{array}{l}\text { Organization does not prevent the use of alternative forest } \\
\text { resources by the local population }\end{array}$ \\
\hline & & 1.5. & 2 & $\begin{array}{l}\text { Incomes of local population decreases by the control of } \\
\text { illegal nature resource use }\end{array}$ \\
\hline \multirow[b]{2}{*}{$\begin{array}{l}\text { Lack of silviculture (cut \& go } \\
\text { practice) }\end{array}$} & \multirow[b]{2}{*}{2} & 5.1. & 3 & $\begin{array}{l}\text { Forest management is according to the management plan } \\
\text { of the organization }\end{array}$ \\
\hline & & 6.3 . & 3 & $\begin{array}{l}\text { Negative impacts of forest operations is reduced by } \\
\text { mimicking natural forest dynamics }\end{array}$ \\
\hline \multirow[b]{3}{*}{$\begin{array}{l}\text { Primary and intact forests as } \\
\text { main timber source }\end{array}$} & \multirow[b]{3}{*}{2} & 9.1. & 4 & HCVF are determined \\
\hline & & 5.1. & 3 & Reduced logging in primary forests \\
\hline & & 6.1. & 3 & $\begin{array}{l}\text { Negative impacts of forestry on HCVF are assessed and } \\
\text { considered in planning and implementing management } \\
\text { operations }\end{array}$ \\
\hline \multirow[b]{2}{*}{ Failure to involve stakeholders } & \multirow[b]{2}{*}{1} & 2.2. & 4 & $\begin{array}{l}\text { Local people, authorities, administrations and forest } \\
\text { managers are interviewed }\end{array}$ \\
\hline & & 3.1. & 4 & $\begin{array}{l}\text { Indigenous peoples are identified, informed and consulted. } \\
\text { Disputes and grievances are solved }\end{array}$ \\
\hline
\end{tabular}




\begin{tabular}{|c|c|c|c|c|}
\hline & & 7.4. & 4 & $\begin{array}{l}\text { The public can access the MP except for confidential } \\
\text { information }\end{array}$ \\
\hline & & 9.2 . & 4 & $\begin{array}{l}\text { Organization carries out consultations with stakeholders in } \\
\text { order identify, map and prepare protection measures for } \\
\text { HCVF }\end{array}$ \\
\hline & & 1.6. & 3 & $\begin{array}{l}\text { In general, stakeholders are involved in decision-making } \\
\text { processes }\end{array}$ \\
\hline & & 3.2 . & 3 & $\begin{array}{l}\text { Organization carries out consultations with indigenous and } \\
\text { local peoples }\end{array}$ \\
\hline & & 3.3. & 3 & $\begin{array}{l}\text { Organization carries out consultations with indigenous and } \\
\text { local people about special sites }\end{array}$ \\
\hline & & 4.4. & 3 & $\begin{array}{l}\text { Staff, local people and other stakeholders are engaged in } \\
\text { social impact analysis }\end{array}$ \\
\hline & & 4.5. & 3 & $\begin{array}{l}\text { There is a procedure for the communication between the } \\
\text { organization and local people to resolve grievances and } \\
\text { disputes }\end{array}$ \\
\hline & & 6.2 . & 3 & $\begin{array}{l}\text { Organization carries out consultations with stakeholders } \\
\text { (game specialists, representatives hunters and fishermen) }\end{array}$ \\
\hline & & 8.5 . & 3 & $\begin{array}{l}\text { Monitoring results are available to public while respecting } \\
\text { confidential information }\end{array}$ \\
\hline & & 1.6. & 3 & $\begin{array}{l}\text { The total forest area of the owners/users is included in the } \\
\text { scope of certification. If not then the rationale is available }\end{array}$ \\
\hline & & 5.2. & 3 & $\begin{array}{l}\text { Optimal economic use of forest resources by including } \\
\text { economic analysis in MP }\end{array}$ \\
\hline & & 6.1. & 3 & $\begin{array}{l}\text { OVOS findings are considered in forest management } \\
\text { planning and implementation }\end{array}$ \\
\hline Poor management & 1 & 7.1. & 3 & $\begin{array}{l}\text { Description of long-term management objectives, } \\
\text { harvesting system }\end{array}$ \\
\hline & & 5.6. & 4 & $\begin{array}{l}\text { AAC calculation takes into account all areas where } \\
\text { cuttings is not allowed or restricted and economically } \\
\text { inaccessible }\end{array}$ \\
\hline & & 1.6. & 3 & ACC calculation considers total leased area \\
\hline & & 5.1. & 3 & ACC adequate to exploitable leased forest area \\
\hline & & 6.1. & 3 & ACC calculation considers total leased area \\
\hline Inadequate calculation of AAC & NA & 7.1. & 3 & MP provides rational for AAC and planned harvest level \\
\hline Outdated legislation & NA & 1.1. & 3 & $\begin{array}{l}\text { Negative influence of ineffective norms of current } \\
\text { legislation for forests and forestry is reduced by FSC } \\
\text { requirements }\end{array}$ \\
\hline & & 5.1. & 4 & $\begin{array}{l}\text { Effective implementation of results of economic analysis } \\
\text { maintains sustainability of companies in the long-term }\end{array}$ \\
\hline Subsistence economy & NA & 5.4. & 3 & Local economy is more stable \\
\hline
\end{tabular}


Annex 6: Identified threats that were influenced by FSC Criteria and changed into a result.

\begin{tabular}{|c|c|c|c|}
\hline Threat & 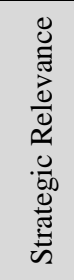 & Threat-reduction result & 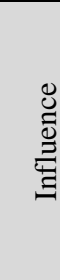 \\
\hline Large scale deforestation & 3 & Reduced percentage of clear-cuts & 4 \\
\hline Forest infrastructure & 3 & Reduced negative impact of infrastructure & 3 \\
\hline Road construction (non-forest) & 3 & Reduced negative impact of infrastructure & 3 \\
\hline Overharvesting of timber resources & 3 & Reduced overharvesting of timber resources & $\mathbf{3}$ \\
\hline Extreme weather events & 3 & No result & $\mathrm{NA}$ \\
\hline $\begin{array}{l}\text { Changed relief in cutting sites (piled up soil } \\
\text { and residues) }\end{array}$ & 3 & No result & $\mathrm{NA}$ \\
\hline Harvesting in HCVF, including intact forests & 2 & Reduced logging in $\mathrm{HCVF}$ & 4 \\
\hline Too big size of clear cuts & 2 & Smaller size of clear-cuts & 4 \\
\hline Hydro melioration & 2 & Reduced hydro melioration & 4 \\
\hline Excess of allowed cut during selective logging & 2 & $\begin{array}{l}\text { Lower excess of allowed cut during selective } \\
\text { logging }\end{array}$ & 4 \\
\hline Damage to trees during selective cutting & 2 & Selective logging without damaging trees & 4 \\
\hline Excessive domestic reindeer pastures & 2 & $\begin{array}{l}\text { Negotiations and agreements with communities } \\
\text { about location of pastures }\end{array}$ & 3 \\
\hline Overhunting & 2 & No result & $\mathrm{NA}$ \\
\hline Introduction of alien animal species & 2 & No result & $\mathrm{NA}$ \\
\hline Gathering of forest litter & 2 & No result & 2 \\
\hline $\begin{array}{l}\text { Unsustainable harvesting of non-timber forest } \\
\text { resources }\end{array}$ & 1 & $\begin{array}{l}\text { More sustainable use of non-timber forest } \\
\text { products }\end{array}$ & 4 \\
\hline $\begin{array}{l}\text { Deterioration of quality and composition of } \\
\text { soil from economic activities }\end{array}$ & 1 & $\begin{array}{l}\text { Reduced deterioration of soil quality and less } \\
\text { change of soil composition }\end{array}$ & 4 \\
\hline Forest fires & NA & Reduced forest fires & 4 \\
\hline Hydrological changes & NA & Hydrological changes are prevented & 3 \\
\hline Water pollution & NA & Water quality is maintained & 3 \\
\hline
\end{tabular}


Annex 7: Identified stresses that were influenced by FSC Criteria and changed into a result.

\begin{tabular}{|c|c|c|c|}
\hline Stress & 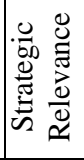 & Stress-reduction result & $\begin{array}{l}\stackrel{\circlearrowright}{\Xi} \\
\stackrel{\Xi}{\Xi} \\
\stackrel{\Xi}{\Xi}\end{array}$ \\
\hline Number of habitat is reduced & 3 & Habitat, e.g. HCVF is maintained & 3 \\
\hline More homogenous and contrast spatial structure & 3 & Less homogeneity of landscape & 3 \\
\hline Diversity of forest ecosystem is reduced & 3 & Loss of diversity is decelerated & 3 \\
\hline Shortened fire cycle & 2 & Reduced anthropogenic forest fires & 4 \\
\hline Contamination of surface and underground water & 2 & $\begin{array}{l}\text { Water quality is improved through reduced } \\
\text { pollution }\end{array}$ & 3 \\
\hline $\begin{array}{l}\text { Change of forest age distribution - less very old } \\
\text { trees }\end{array}$ & 2 & Some old trees in primary forests remain & 3 \\
\hline Vulnerable species extinction & 2 & $\begin{array}{l}\text { Rare, threatened and endangered species and } \\
\text { their habitats are protected }\end{array}$ & 3 \\
\hline Changed water regime & 2 & Hydrological regimes are slightly improved & 3 \\
\hline Forest drying out & 2 & Desiccation of forests is reduced & 3 \\
\hline Decrease of forest regeneration rate & 2 & Better forest regeneration & 3 \\
\hline $\begin{array}{l}\text { Change of distribution area/ area of available } \\
\text { habitats }\end{array}$ & 2 & $\begin{array}{l}\text { Habitats of identified rare, threatened and } \\
\text { endangered species remain }\end{array}$ & 3 \\
\hline Changed frequency and intensity of floods & 2 & Floodplains are maintained & 3 \\
\hline Dissociation of populations - gene flow & 2 & No result & NA \\
\hline Change of wood species - changed cycles & 2 & No result & NA \\
\hline Frequency and area of deadfall & 2 & No result & NA \\
\hline Nutrient return to soil & 2 & No result & NA \\
\hline Remineralisation - loss of fertility & 2 & No result & NA \\
\hline Disturbance of (big) animals & 1 & $\begin{array}{l}\text { Less disturbance of identified rare, threatened } \\
\text { and endangered species }\end{array}$ & 3 \\
\hline $\begin{array}{l}\text { Growth of moose populations - elimination of } \\
\text { plants }\end{array}$ & 1 & Control of moose and reindeer populations & 3 \\
\hline Excessive mire areas & 1 & No result & 2 \\
\hline Decreasing forest density & 1 & No result & 2 \\
\hline Increasing gap dynamics & 1 & No result & 1 \\
\hline Changed routes of animal migration & 1 & No result & NA \\
\hline Changed dynamics of forest animal populations & 1 & No result & NA \\
\hline Deceleration of forest growth & 1 & No result & NA \\
\hline Outbreak of insects, fungi, etc. & 1 & No result & NA \\
\hline Emerging new species - introduction & 1 & No result & NA \\
\hline Keystone species influence (beavers etc.) & NA & $\begin{array}{l}\text { Less disturbance of identified rare, threatened } \\
\text { and endangered species }\end{array}$ & 3 \\
\hline $\begin{array}{l}\text { Formation of new habitat for diversity of flora } \& \\
\text { fauna }\end{array}$ & NA & No result & 2 \\
\hline $\begin{array}{l}\text { Change of numbers/ composition of species } \\
\text { (regulators and pests) }\end{array}$ & NA & No result & 2 \\
\hline Fragmentation of forest habitats & NA & No result & 1 \\
\hline Change of population size & NA & No result & NA \\
\hline
\end{tabular}

